\title{
Doživljaj zajednice i odnos prema kulturnoj baštini iz perspektive dviju etničkih skupina: primjer općine Vojnić
}

\author{
DOI: https://doi.org/10.11567/met.35.1.3 \\ UDK: 316.3564:725.945(497.529Vojnić) \\ Izvorni znanstveni rad \\ Primljeno: 29.04.2019. \\ Prihvaćeno: 17.06.2019.
}

\section{Natalija Oparnica}

Malmö

oparnica.natalija@gmail.com

\section{Ana Opačić}

Studijski centar socijalnog rada, Pravni fakultet, Sveučilišta u Zagrebu, Zagreb ana.opacic@pravo.hr

\section{SAŽETAK}

Temelj rada su koncepti doživljaj zajednice i valorizacija kulturne baštine na primjeru multietničke općine Vojnić s kulturnom baštinom na Petrovoj gori od umjetničke i povijesne važnosti. Kulturna baština omogućuje jačanje lokalnog identiteta, a time i doživljaj zajednice, kao most između prošlosti zajednice i sadašnjih iskustava. U dinamici baštine i identiteta stanovnici imaju važnu ulogu svojim odnosom prema baštini. Istraživanjem smo željeli utvrditi razlike među ispitanicima u doživljaju zajednice i valorizaciji kulturne baštine Petrove gore s obzirom na sociodemografske karakteristike ispitanika te utvrditi povezanost dimenzija doživljaja zajednice i valorizacije kulturne baštine. U anketnom istraživanju sudjelovalo je sto ispitanika. Rezultati pokazuju niže procjene doživljaja zajednice u odnosu na valorizaciju baštine. U doživljaju zajednice nema razlika po spolu ni povezanosti s duljinom stanovanja u zajednici. Mlađi stanovnici pozitivniji su prema lokalnom vodstvu i rješavanju problema, a obrazovaniji su pozitivniji prema utjecaju zajednice na pojedinca i okruženje. Hrvati u odnosu na Srbe više prepoznaju identitet zajednice te višim procjenjuju utjecaj na okruženje, ali imaju manje kontakta s članovima zajednice. Doseljeni stanovnici imaju snažniji doživljaj zajednice, više vide identitet zajednice te su pozitivniji prema utjecaju zajednice i njezinu vodstvu i rješavanju problema. Stanovnici daju visoke procjene valorizacije baštine. Žene obilaze lokalitete češće, a nema povezanosti s dobi ni s duljinom stanovanja. Srbi imaju višu razinu valorizacije baštine u odnosu na Hrvate, a iste razlike uočavaju se između domicilnih i doseljenih stanovnika. Postoji povezanost između doživljaja zajednice i valorizacije kulturne baštine. Rezultati upućuju na nedovoljnu integriranost baštine u konstrukciju lokalnog identiteta. Edukacija stanovnika o baštini te uključivanje stanovnika u aktivnosti povezane s baštinom mogli bi pridonijeti većoj uzajamnosti baštine i lokalnog identiteta s krajnjom svrhom unapređenja lokalnog razvoja.

KLJUČNE RIJEČI: doživljaj zajednice, kulturna baština, valorizacija baštine, identitet zajednice, razvoj zajednice 


\section{UVOD}

U radu se tematizira koncept doživljaja zajednice i valorizacije kulturne baštine na primjeru općine koja je multietnička, nalazi se u razvojnim izazovima i odlikuje se kulturnom baštinom od umjetničke, povijesne, pa i simbolične važnosti koja nadilazi okvir same zajednice. Doživljaj zajednice preduvjet je konstrukcije lokalnog identiteta, dok baština kao vidljivi pokazatelj kolektivne memorije posreduje $\mathrm{u}$ stalnom stvaranju identiteta između prošlosti i sadašnjosti. Baština je resurs koji je prijeko potrebno staviti u funkciju kako bi socioekonomski deprivirana zajednica počela snažnije upravljati vlastitim razvojem.

Povijesna i simbolična važnost baštine Petrove gore povezana s kontekstom Drugoga svjetskog rata istovremeno je njezina prilika i prijetnja s obzirom na ambivalentan odnos širega društvenog okruženja. Pitanje je u kojoj se mjeri ta ambivalentnost zrcali na lokalnoj razini. Valoriziranje baštine i njeno integriranje u lokalni identitet postaju dio procesa društvenog pregovaranja i izgradnje međuetničkog suživota. Studija provedena u općini Vojnić iz navedenih nam se razloga čini prikladnom kako bismo utvrdili relacije između procesa važnih za daljnji razvoj zajednice.

\section{Doživljaj zajednice}

U literaturi istraživanja zajednice doživljaj zajednice (engl. sense of community) jedan je od bitnih konstrukata koji se povezuje sa socijalnim kapitalom i može se smatrati preduvjetom pripadnosti zajednici i stvaranja snažnih identitetskih veza (Farahani, 2016). Doživljaj zajednice upotrebljavamo sukladno određenju autora McMillana i Chavisa (1986) koji ističu četiri temeljna elementa: članstvo, utjecaj, integraciju i podmirenje potreba te dijeljene emocionalne veze. Članstvo se temelji na doživljaju da osoba pripada određenom kolektivu s jasnim osjećajem za granice tko mu pripada, a tko ne. Ponekad se granice vizualno ističu odabirom odjeće, jezika ili rituala, a u podlozi definiranih granica su zajednički simbolički sustavi koji se prenose putem kolektivnih prezentacija mitova, običaja, ceremonija, kulturnog naslijeđa i sl. Dakako, stvaranje granica članstva može pridonijeti razdvajanju grupa stanovništva jednih od drugih, odnosno isključivanju i podjeli na »nas i njih « (Pretty i Bishop, 2006). Članstvom osoba stječe dobit emocionalne sigurnosti i zaštite, ali $u$ isto vrijeme dobiva poticaj osobnog zalaganja za dobrobit skupine. Drugi je element utjecaj koji sadržava doživljaj da pojedinac znači skupini, ali i da skupina znači pojedincu. Drugim riječima, ne očekuje se konformizam, već mogućnost da utjecaj bude obostran, odnosno 
da pojedinac može djelovati na kolektiv, ali i da kolektiv može djelovati na njega. To je posebice slučaj u visoko povezanim zajednicama. Ipak, što je doživljaj kohezije u zajednici veći, raste i utjecaj zajednice na članstvo koji potiče konformizam s obzirom na to da je i drugim članovima bitno znati da ostali razmišljaju kao oni. Treći je element doživljaja zajednice integracija i podmirenje potreba koji je pragmatičan odgovor na pitanje zašto su ljudi uopće članovi zajednice. Svojim članstvom pojedinci očekuju pozitivna potkrepljenja kao što su društveni status, podmirenje potreba te upotreba tuđih ili razvoj vlastitih kompetencija. No za koncept zajednice bitno je da pojedinci dijele sličan pogled na to što su njihove potrebe (kroz zajedničke vrijednosti) te kojim redom očekuju njihovo podmirivanje. Stoga će biti zainteresirani i za podmirenje tuđih potreba njegujući reciprocitet. Posljednji su element doživljaja zajednice prema McMillanu i Chavisu (1986) dijeljene emocionalne veze. Taj element autori ponajviše pripisuju zajedničkoj povijesti, za koju nije nužno da su stanovnici u njoj sudjelovali, ali se mogu s njom identificirati. Ljudi će razvijati zajedničke veze ako imaju više pozitivnih interakcija, ako postoji doživljaj dovršetka razvojnih zadataka zajednice te kada imaju iskustvo zajedničkog sudjelovanja u važnim događajima za zajednicu (posebice kriznim). Dodatno, pojedinci koji imaju prilike investirati više svojih resursa u zajednicu te doživljavaju da ih zajednica cijeni osjećat će jače emocionalne veze. U nekim zajednicama emocionalne veze povezane su s posebnih duhom tipičnim za zajednicu koji je teško objasniti, a neki ga autori nazivaju »zajednicom duha « (Bernard, 1973, prema McMillan i Chavis, 1986). Zaključno, autori predlažu definiciju doživljaja zajednice kao osjećaj članova da pripadaju, da znače jedni drugima i skupini te dijele vjeru da će njihove potrebe biti podmirene kroz posvećenost zajedništvu (McMillan, 1976, prema McMillan i Chavis, 1986: 9). Ovome teorijskom doprinosu Obst, Smith i Zinkiewicz (2002) dodaju dimenziju svjesne identifikacije, odnosno osvještavanje sebe kao stanovnika.

Različiti autori u različitim kontekstima utvrdili su povezanost doživljaja zajednice s drugim konstruktima i obilježjima pojedinaca. Najčešće se konstrukt mjerio na individualnoj razini, iako nekolicina istraživanja promatra doživljaj zajednice kao kontekstualnu varijablu (Perkins i Long, 2011).

Doživljaj zajednice rezultat je određenih individualnih i kontekstualnih obilježja zajednice. Istraživanja koja uključuju individualne sociodemografske prediktore govore da će veći doživljaj zajednice imati stariji stanovnici, umirovljenici (French i sur., 2014; Pampalon i sur., 2007), stanovnici koji duže žive u zajednici (Long i Perkins, 2007; French i sur., 2014; Prezza i sur., 
2009), stanovnici sa srednjom stručnom spremom jer se smatra da imaju manju mobilnost (French i sur., 2014; Prezza i sur., 2009) te stanovnici koji imaju djecu (French i sur., 2014; Obst, Smith i Zinkiewicz, 2002) ili žive s partnerom (Pampalon i sur., 2007; Prezza i sur., 2009). Što se spola tiče, autori ne ističu jasne razlike, osim istraživanja Pampalona i suradnika (2007) koje upućuje da će u pogledu doživljaja zajednice žene biti kritičnije prema procjeni socijalne kohezije i problema u zajednici, kao i stanovnici s niskim dohotkom. Individualni prediktori doživljaja zajednice jesu i oni koji se tiču razine sudjelovanja pojedinca u lokalnim procesima. Viši doživljaj zajednice imaju stanovnici koji sudjeluju u aktivnostima lokalnih skupina (Long i Perkins, 2007; Prezza i sur., 2009), koji više vremena provode u javnim prostorima u četvrti (French i sur., 2014), stanovnici koji su spremniji na aktivniji odnos prema susjedima, imaju bolji odnos sa susjedima i spremni su poduzeti aktivnosti neformalne socijalne kontrole (Long i Perkins, 2007) te koji imaju snažnije izraženu privrženost mjestu kao emocionalno obojeni konstrukt (Long i Perkins, 2007). Viši doživljaj zajednice imat će i stanovnici koji kao mjesto života vide prostor šire od ulice ili bloka u kojem žive (Obst, Smith i Zinkiewicz, 2002), stanovnici koji vjeruju da njihova zajednica može ostvariti ciljeve te stanovnici koji više njeguju vrijednost komunitarijanizma, odnosno procjenjuju da im je zajednica važna (Long i Perkins, 2007). I neki vrlo specifični aspekti života u zajednici mogu pridonijeti doživljaju zajednice. Tako će viši doživljaj zajednice imati stanovnici koji više vremena provode u parkovima u zajednici (French i sur, 2014; Prezza i Pacilli, 2007), koji više vide dobiti od javnih parkova i posredstvom tog prediktora imaju veći doživljaj sigurnosti četvrti (Gueorguiev, Gómez i Hill, 2007). Doživljaju zajednice pridonose veća autonomna mobilnost, odnosno sloboda boravka djece $u$ dobi od osam do deset godina bez nadzora roditelja na javnim mjestima u zajednici te manji strah od zločina (Prezza i Pacilli, 2007).

Posebno je važno sagledati doživljaj zajednice iz perspektive mlađih stanovnika koji teže participiraju u lokalnim aktivnostima i imaju slabiju moć, što je još izraženije kod socijalno depriviranih mladih (Evans, 2007). Prema Evansu (2007), oni mladi koji su na pragu adolescencije i školovanjem u zajednici vezani uz zajednicu imat će viši doživljaj zajednice. No kada mladi ulaze u razdoblje tranzicije prema odrasloj dobi, ako im se ne omogući aktivno sudjelovanje u zajednici, njihov će se doživljaj zajednice smanjivati.

Obilježja zajednice također pridonose doživljaju zajednice. Kontekstualni prediktori koji su pozitivno povezani s doživljajem zajednice jesu kolektivna učinkovitost, građanska participacija i privrženost mjestu (Long i Perkins, 
2007). Veći doživljaj zajednice zabilježen je u ruralnim zajednicama (Obst, Smith i Zinkiewicz, 2002) te u rjeđe naseljenim područjima (French i sur., 2014). Etnička heterogenost zajednice uglavnom se povezuje s nižim doživljajem zajednice (Castellini i sur., 2011; Hombrados-Mendieta, Gómez-Jacinto i Dominguez-Fuentes, 2009) te se pojavljuje negativna korelacija između doživljaja zajednice i isključujuće strategije dijela stanovništva prema etničkim manjinama (Castellini i sur., 2011). Dublje uvide u ovaj fenomen dali su Long i Perkins (2007), koji su ustvrdili da je viši doživljaj zajednice u zajednicama višeg dohotka i više etničke heterogenosti, dok je niži u zajednicama nižeg dohotka i niže etničke heterogenosti, što zapravo više dovodi u vezu doživljaj zajednice s razinom dohotka stanovnika. S druge strane, niži doživljaj zajednice pojavljuje se i kod manjinskih etničkih skupina. Barbieri i Zani (2015) istraživali su doživljaj zajednice unutar tri etničke skupine u Italiji (Albanci, Marokanci i Kinezi) te utvrdili da je viši doživljaj zajednice s kojom se identificiraju, najčešće zajednicom porijekla (relacijski), a manji teritorijalni doživljaj zajednice u kojoj stvarno žive. Teritorijalni doživljaj zajednice veći je kod onih ispitanika koji imaju izraženiji talijanski identitet.

Doživljaj zajednice pridonosi dobrobiti pojedinca i zajednice. Tako će na individualnoj razini viši doživljaj zajednice imati pozitivne učinke na etnički identitet i psihološko osnaživanje, na dobrobit pojedinca (Lardier, 2018), na kvalitetu života posebice u domeni psihološke dobrobiti i fizičkog zdravlja (Gattino i sur., 2013; Pampalon i sur., 2007) i na zadovoljstvo životom (Prezza i sur., 2009). Stanovnici s višim doživljajem zajednice bit će zadovoljniji zajednicom (Lardier, 2018), više će se identificirati s njom i imati više povjerenja u lokalnu vlast kao i višu razinu interpersonalnog povjerenja (Prezza i sur., 2009). Mladi s višim doživljajem zajednice, posebice u dimenziji članstva i višom pripadnosti, imat će izraženije namjere ostanka u zajednici (Theodori i Theodori, 2015). Autori Theodori i Theodori (2015) ističu da će namjere ostanka iskazati mladi sa srednjim obrazovnim aspiracijama te se potvrđuje da je upravo ta skupina mladih ona koja može predstavljati polugu demografskog osnaživanja u slabije razvijenim zajednicama. Doživljaj zajednice povezan je s jačim socijalnim kapitalom na individualnoj i na kolektivnoj razini (Perkins i Long, 2011). Dvije kvalitativne studije u kojima su sudionici iskazivali svoje viđenje konstrukta doživljaja zajednice upućuju na povezanost s otpornošću zajednice (Pretty i sur., 2006) i jačanjem socijalnih odnosa. Mannarini i Fedi (2009) analizirali su upotrijebljene riječi iz 76 intervjua te utvrdili da je doživljaj zajednice povezan s dijeljenjem normi, afektivnom dimenzijom kroz povjerenje, veze i identifikaciju, participacijom u zajednici te vođenjem uobičajenoga svakodnevnog života u zajednici. 
Za mlade stanovnike zajednice doživljaj zajednice pomaže razvoju moralnog aktivizma i daljnjim pozitivnim ishodima u adolescenciji (Evans, 2007), a mladi doživljaj zajednice povezuju s iskazivanjem mišljenja, dobivanjem moći i primanjem odgovarajuće podrške odraslih uz primjerenu razinu izazova (Evans, 2007).

\section{Važnost kulturne baštine za jačanje identiteta zajednice}

Pojam kulturne baštine odnosi se na »dostignuća što su nam preci ostavili u jeziku i književnosti, graditeljstvu i likovnim umjetnostima, uključujući narodnu umjetnost, u glazbi, kazalištu, filmu, znanosti i u drugim područjima koja zajedno čine ukupnost kulture« (Marasović, 2001, prema Šošić, 2014: 833). Kulturna baština važan je čimbenik identiteta zajednice, međutim taj odnos nije statičan. Kako se mijenja vrednovanje kulturne baštine, tako se i njena važnost za identitet može u konstantnim društvenim promjenama preispitivati. Društvene skupine koje čine zajednicu mogu pregovarati, pa i nadmetati se o tome koji će aspekt njihova identiteta u danome povijesnom trenutku biti dominantan, pa će sam identitet ovisiti o povijesnim prilikama (Rubić, 2005).

Zašto je baština tako duboko isprepletena s pitanjem identiteta? Reeves i Plets (2016: 203) ponajviše je povezuju s kolektivnom memorijom zajednice koja ima »neizmjernu važnost za očuvanje održivih zajednica i stabilnosti«. Baština omogućuje svijest o prošlome, a identitet se neprestano izgrađuje $\mathrm{u}$ dinamici sadašnjih potreba, razmišljanja i življenja u odnosu na svijest o prošlosti i poštovanje prošlosti (Reeves i Plets, 2016). Sadašnje stanje stoga omogućuje da se baština kao produkt prošlosti neprestano iznova čita na drugačiji način. U kontekstu teme ovog rada posebno je važno istaknuti kako baština igra važnu ulogu kada se redefiniraju odnosi među skupinama. Tako ona postaje čimbenik kohezije, samopouzdanja i temelj davanja legitimiteta sociokulturnim interesima određene zajednice, ali može postati i točka prijepora, izvor konflikta političkog i emocionalnog naboja reflektirajući odnose koji postoje na širim društvenim razinama (Reeves i Plets, 2016). U toj dinamici baštine i identiteta ključnu ulogu igraju sami članovi zajednice svojim kognitivnim, emocionalnim i ponašajnim odnosom prema baštini.

Članovi zajednice sudjelovanjem u kulturnim aktivnostima bitnima za identitet zajednice akumuliraju memoriju koja pridonosi sinkronizaciji vlastitoga i kolektivnog identiteta (Williams i Vaske, 2003, prema Schuster i sur., 2011), čime dalje osnažuju privrženost zajednici (Schuster i sur., 2011). Oni igraju važnu ulogu u prepoznavanju ili identifikaciji onih dobara koja 
predstavljaju baštinu (Opačić, 2019), a u svom pregledu istraživanja Harill (2004) zaključuje kako je privrženost zajednici uglavnom u pozitivnoj vezi s otvaranjem zajednice prema turističkoj valorizaciji baštine. Aktivan i održiv odnos lokanog stanovništva prema baštini u literaturi vezan je uz koncept baštinske pismenosti (Babić, Vatan Kaptan i Masriera Esquerra, 2019: 8) prepoznajući pravo zajednice da »oblikuje, definira baštinu i upravlja njome na način koji će najbolje oblikovati njen napredak i razvoj i pridonijeti općem dobru«. Kako bi se baština mogla staviti u funkciju aktivnoga održivoga korištenja, važno je utvrditi kako se lokalno stanovništvo prema njoj odnosi te ispitati taj odnos s aspekta doživljaja same zajednice kao inherentnog pokazatelja njihove povezanosti s prostorom življenja.

\section{Kulturna baština Petrove gore i kontekst općine Vojnić}

U ovom radu fokusirat ćemo se na baštinu na području Petrove gore, koja geografski ulazi u područje Korduna. Područje Petrove gore kao istočna granica Korduna (Zatezalo, 2010) dijeli bogato povijesno naslijeđe šire regije, počevši od prapovijesti i Lasinjske kulture te kasnije u željeznom dobu sa zajednicom Kolapijana i Japodana (Škiljan, 2007). U srednjem vijeku za ovo područje posebno je važna bitka između Kolomana Arpadovića i posljednjega hrvatskoga kralja Petra Svačića, u čijem su spomenu na Petrovoj gori obilježeni lokaliteti poput Kraljeva groba. Iz srednjeg vijeka značajan je i samostan pavlina, koji je kroz povijest pretrpio cikluse razaranja i obnova, no danas dio sačuvanih zidina postaje sastavni dio baštine na Petrovoj gori. Povijest ovog područja obilježavaju važne bitke i procesi kao što su osvajanja Osmanlija, djelovanje Frankopana i Zrinskih i Napoleonova vlast koja zadržava Vojnu krajinu do njezina spajanja s Banskom Hrvatskom 1881. U 20. stoljeću stanovništvo i područje Korduna bili su iscrpljeni ratnim događanjima, počevši od Prvoga svjetskog rata, posebice u Drugome svjetskom radu i konačno u Domovinskom ratu. U kontekstu baštine na Petrovoj gori posebno je važno istaknuti Drugi svjetski rat, kad se na području Korduna pojavljuju odredi partizana neprestano izloženi konstantnim borbama s vojskom NDH. Budući da je u vrijeme rata bilo puno ranjenika, a šuma je bila dobro skrovište, već sredinom kolovoza 1941. Savo Zlatić, na prijedlog Jakova Kranjčevića, gradi bolnicu s još deset mladića (Zatezalo, 2010). Bolnica je prve ranjenike primila već $u$ listopadu iste godine. U najbližoj okolici nalazilo se još pet zemunica, koje su dobro skrivale ranjenike tijekom neprijateljskih napada. Bolnica je spaljena 1942. u svibanjskoj ofenzivi. Krajem svibnja 1942. ranjenici se sele u novu bolnicu u predjelu Pišin gaj, koja će poslije postati Centralna bolnica, te je radila sve do svibnja 1945., kada se 
seli u oslobođeni Karlovac. Uz te dvije postojalo je još šest bolnica: Civilna bolnica, Španovo brdo, Partizanska bolnica Kupinjak, Partizanska bolnica Perna, Partizanska bolnica Pecka i Partizanska bolnica Sivac ili Gaj, koje nisu sačuvane. Do 1995. bila je u potpunosti sačuvana Centralna bolnica, ali je nakon rata prepuštena propadanju. Riječ je o jedinom takvom objektu na području Hrvatske, te bi bilo iznimno važno obnoviti je, kao što je to učinila Slovenija. Naime Baza 20 i Partizanska bolnica Franja obnovljene su $\mathrm{i}$ iskorištene $\mathrm{u}$ turističke svrhe (Zatezalo, 2010). Na vrhu Petrove gore, kao spomen poginulim partizanima, stoji spomenik Vojina Bakića. Spomenik je sagrađen 1978., a otvorio ga je 1981. Jure Bilić, predsjednik Sabora SR Hrvatske (Škiljan, 2007). U temelje spomenika ugrađena je kosturnica s ostacima 72 partizana koja su stradala u borbi 1. travnja 1942. Prizemlje spomenika previđeno je za galerije, knjižnice, čitaonice te upravu Memorijalnog parka Petrova gora. U visokom dijelu bili su prostori za muzej revolucije, a na trideset sedmome metru spomenika uzdiže se vidikovac. Podzemni dio nikad nije bio završen, a previđen je bio za prikazivanje filmova, kongresne dvorane, konferencije, nastavu, simpozije i sl. Danas je spomenik u devastiranom stanju te još uvijek nema jasne strategije njegove obnove.

Današnji uvjeti života stanovništva obilježeni su ratnim događanjima u Domovinskom ratu od 1991. do 1995. s obzirom na koja je općina Vojnić u prvoj skupini područja posebne državne skrbi (Zakon o područjima posebne državne skrbi, $N N$, 86/08) s indeksom razvijenosti od 89,870 prosjeka Hrvatske i u najnižoj razvojnoj skupini potpomognutih područja. Ratna zbivanja ostavila su velike gospodarske, ekonomske i društvene posljedice s izmijenjenom slikom sastava stanovništva u odnosu na stanje prije devedesetih.

Prema popisu stanovništva iz 1991., na području općine Vojnić živjelo je 8236 stanovnika, od čega je 7366 bilo srpsko stanovništvo (89,44\%), a 116 hrvatsko (1,41\%). U popisu 2001. situacija izgleda značajno drugačije, pa je tako u općini 5495 stanovnika s 1980 Hrvata (36,03\%) i 2747 (49,99\%) Srba. Slični trendovi smanjenja broja stanovnika nastavljaju se prema popisu 2011., kada u Vojniću živi 4767 stanovnika, od čega je 1769 Hrvata (37,11\%), a $2130(44,68 \%)$ Srba. Osim toga valja istaknuti da je stopa rizika od siromaštva 2011. prema dohodovnoj metodi u općini Vojnić bila izuzetno visoka $57,2 \%$ u odnosu na stopu na nacionalnoj razini koja je 19,2\% (Državni zavod za statistiku, 2011). Sve ovo upućuje da je općina Vojnić dekonstruirana zajednica (Miljenović i Žganec, 2011) u kojoj su nakon ratnih događanja narušene sve vitalne funkcije. Snižen je životni standard, dramatične promjene dogodile su se u strukturi i odnosima etničkih skupina te je na makrorazini 
oslabljeno funkcioniranje zajednice iz fizičkoga, institucionalnog i kulturnog aspekta. Zadaća dekonstruiranih zajednica jest ponovna izgradnja njihova tkiva i temeljnih struktura s priljevom novih resursa.

Imajući u vidu kontekst multietničke zajednice koja se susreće s razvojnim izazovima, ovim radom želimo dovesti u vezu koncept doživljaja zajednice i odnosa prema kulturnoj baštini koja istovremeno otvara pogled prema prošlosti i budućnosti te može predstavljati medij rekonstrukcije lokalnog identiteta.

\section{CILJ I PROBLEMI ISTRAŽIVANJA}

Cilj istraživanja bio je utvrditi doživljaj zajednice i valorizaciju kulturne baštine stanovništva općine Vojnić kao primjera multietničke zajednice.

Specifični problemi istraživanja jesu:

1. Utvrditi doživljaj zajednice te razlike u doživljaju zajednice s obzirom na sociodemografske karakteristike ispitanika.

2. Utvrditi razinu valorizacije kulturne baštine Petrove gore na području općine Vojnić te razlike $\mathrm{u}$ valorizaciji kulturne baštine Petrove gore $\mathrm{s}$ obzirom na sociodemografske karakteristike ispitanika.

3. Utvrditi povezanost dimenzija doživljaja zajednice i valorizacije kulturne baštine na području općine Vojnić.

\section{PROVEDBA ISTRAŽIVANJA}

\section{Opis uzorka i provedba istraživanja}

Uzorak $\mathrm{u}$ istraživanju bio je prigodan, no nastojalo se podjednako obuhvatiti stanovnike različite etničke pripadnosti i dobi. Istraživačica, jedna od autorica ovog rada, samostalno je kontaktirala ispitanike, koji su je upućivali na sljedeće putem poznanstava tj. prilikom kreiranja uzorka i prikupljanja podataka korištena je metoda snježne grude. Podaci su prikupljeni metodom anketiranja licem u lice, a ispitanicima je prethodno objašnjena svrha istraživanja, dobivena je njihova usmena suglasnost i obrazložena im je zaštita anonimnosti.

U istraživanju je sudjelovalo 100 ispitanika, od čega 52 muškarca (52\%) i 48 žena (48\%). Nešto je više ispitanika srpske nacionalnosti ( $\mathrm{N}=52$ ili $52 \%) \mathrm{u}$ odnosu na ispitanike hrvatske nacionalnosti $(\mathrm{N}=41,41 \%)$, dok se preostalih 6\% ispitanika izjašnjava kao Albanci ili Bošnjaci. Polovinu uzorka čini 
domicilno stanovništvo, dok drugu polovinu (50\%) doseljeno stanovništvo. Domicilno stanovništvo uglavnom je srpske nacionalnosti (94\%), dok je doseljeno stanovništvo uglavnom hrvatske nacionalnosti $(76 \%)\left(\chi^{2}=66,64 ; \mathrm{df}\right.$ $=2 ; p=0,000)$.

Što se tiče obrazovne strukture ispitanika, većina ima završenu srednju školu (68\%), 27\% ima završeno više ili visoko obrazovanje, a 5\% nema završenu osnovnu školu. Prosječna je dob ispitanika 36,32 godine ( $\mathrm{SD}=13,7)$, dok je prosječna duljina života u zajednici 25,11 godina $(S D=14,53)$. Detaljnija dobna struktura i duljina života u zajednici navedene su u tablici 1.

Tablica 1. Dobna struktura i duljina života ispitanika u zajednici Table 1. Age of respondents and duration of living in the community

\begin{tabular}{lc}
\hline DOB ISPITANIKA & \% \\
\hline $19-29$ & 38 \\
\hline $30-39$ & 24 \\
\hline $40-49$ & 19 \\
\hline $50-59$ & 13 \\
\hline 60 i više godina & 6 \\
\hline DULJINA ŽIVOTA U ZAJEDNICI & $\%$ \\
\hline Do 10 godina & 14 \\
\hline $11-20$ godina & 44 \\
\hline $21-30$ godina & 17 \\
\hline $31-40$ godina & 9 \\
\hline $41-50$ godina & 6 \\
\hline Više od 50 godina & 10 \\
\hline
\end{tabular}

\section{Istraživački instrumenti}

Primijenjeni upitnik se sastojao se od sljedećih instrumenata i varijabli:

a) sociodemografske karakteristike ispitanika: spol, dob, nacionalnost, obrazovanje, duljinu života u zajednici te pitanje je li ispitanik doselio ili je domicilan stanovnik

b) indeks doživljaja zajednice

c) instrument valorizacije kulturne baštine

d) učestalost posjećivanja kulturnih spomenika

e) procjena mogućnosti korištenja kulturne baštine u različite svrhe. 
Instrument procjene doživljaja zajednice preuzet je od autora McMillana i Chavisa (1986). Primijenjen je indeks doživljaja zajednice s 24 tvrdnje na skali od 1 do 4 (Chavis, Lee i Acosta, 2008). U ovom istraživanju dobivena je nešto drugačija faktorska struktura (tablica 2, tablica 3) u odnosu na izvorni instrument koji sadržava četiri podskale opisane u uvodu. Ukupni koeficijent pouzdanosti Cronbachov alpha iznosi 0,934. Na skali s 24 čestice dobivena je faktorska struktura s pet faktora faktorskom analizom s uključenom Varimax rotacijom. Rezultati na podskalama i ukupni doživljaj pripadnosti zajednici izračunati su kao prosječan odgovor ispitanika na odgovarajućim česticama (tablica 3).

Tablica 2. Faktorska struktura instrumenta doživljaja zajednice

Table 2. Factor structure of the instrument measuring sense of community

\begin{tabular}{lllllll}
\hline & \multicolumn{5}{c}{ FAKTORI } \\
\cline { 2 - 6 } & 1 & 2 & 3 & 4 & 5 \\
\hline
\end{tabular}

FAKTOR 1: EMOCIONALNA VAŽNOST PRIPADNOSTI ZAJEDNICI

1. Većina mojih potreba je zadovoljena zbog činjenice da živim u ovoj zajednici.

0,579

2. Uklapanje u ovu zajednicu je važno za mene.

0,776

3. Vrlo je važno za mene biti dio ove zajednice.

0,844

4. Očekujem da ću biti dio ove zajednice dugo vremena.

0,682

5. Osjećam se dobro zbog toga što sam član ove zajednice.

\section{FAKTOR 2: PREPOZNATI IDENTITET ZAJEDNICE}

6. Članovi zajednice i ja dijelimo iste vrijednosti.

7. Ova zajednica ima simbole i kulturna obilježja po kojima je prepoznatljiva.

8. Članovi ove zajednice dijele važne događaje zajedno kao praznike, proslave ili katastrofe. 0,744

9. Imam vjeru u boljitak ove zajednice. 0,594

10. Ljudi u ovoj zajednici imaju slične potrebe, prioritete, ciljeve.

11. Članovi ove zajednice brinu jedni o drugima. 


\begin{tabular}{crrrrr}
\hline & \multicolumn{5}{c}{ FAKTORI } \\
\cline { 2 - 6 } & 1 & 2 & 3 & 4 & 5 \\
\hline
\end{tabular}

FAKTOR 3: UTJECAJ ZAJEDNICE NA POJEDINCA I OKRUŽENJE

12. Mogu vjerovati ljudima u ovoj zajednici.

0,582

13. Ova zajednica može utjecati na druge zajednice.

0,371

14. Stalo mi je do toga što drugi članovi misle o meni.

0,717

15. Imam utjecaj na to kako će ljudi u zajednici živjeti.

16. Uložio/la sam puno truda da se uklopim u ovu zajednicu.

0,661

\section{FAKTOR 4: VODSTVO U ZAJEDNICI I RJEŠAVANJE PROBLEMA}

17. Ako postoji problem u ovoj zajednici, članovi mogu dobiti rješenje.

18. Ova zajednica ima dobre vođe. 0,654

19. Zajednica uspješno zadovoljava potrebe svojih članova.

20. Kad imam problem, mogu razgovarati o tome s članovima ove zajednice.

0,502

\section{FAKTOR 5: ODRŽAVANJE KONTAKATA S ČLANOVIMA ZAJEDNICE}

21. Poznajem većinu članova ove zajednice.

22. Provodim puno vremena s ostalim članovima zajednice i uživam biti s njima.

23. Većina članova ove zajednice mene poznaje.

24. Biti dio ove zajednice je dio mog identiteta.

Tablica 3. Pouzdanost i ukupni rezultat na podskalama doživljaja zajednice Table 3. Reliability and total result of the sense of community subscales

\begin{tabular}{lccccc}
\hline FAKTOR & $\lambda$ & $\begin{array}{c}\text { \% objašnjene } \\
\text { varijance }\end{array}$ & $\begin{array}{c}\text { Cronbachov } \\
\text { alpha }\end{array}$ & $\begin{array}{c}\text { M (MIN: 1; } \\
\text { MAX: 4) }\end{array}$ & SD \\
\hline $\begin{array}{l}\text { Faktor 1: Emocionalna važnost } \\
\text { pripadnosti zajednici }\end{array}$ & 9,69 & 40,37 & 0,864 & 2,5 & 0,98 \\
\hline $\begin{array}{l}\text { Faktor 2: Prepoznati identitet } \\
\text { zajednice }\end{array}$ & 2,22 & 9,25 & 0,847 & 2,5 & 0,89 \\
\hline
\end{tabular}




\begin{tabular}{lccccc}
\hline FAKTOR & $\lambda$ & $\begin{array}{c}\text { \% objašnjene } \\
\text { varijance }\end{array}$ & $\begin{array}{c}\text { Cronbachov } \\
\text { alpha }\end{array}$ & $\begin{array}{c}\text { M (MIN: 1; } \\
\text { MAX: 4) }\end{array}$ & SD \\
\hline $\begin{array}{l}\text { Faktor 3: Utjecaj zajednice na } \\
\text { pojedinca i okruženje }\end{array}$ & 1,59 & 6,64 & 0,780 & 2,12 & 0,817 \\
\hline $\begin{array}{l}\text { Faktor 4: Vodstvo u zajednici i } \\
\text { jješavanje problema }\end{array}$ & 1,18 & 4,9 & 0,776 & 1,91 & 0,866 \\
\hline $\begin{array}{l}\text { Faktor 5: Održavanje kontakata s } \\
\text { članovima zajednice }\end{array}$ & 1,11 & 4,63 & 0,772 & 2,85 & 0,87 \\
\hline $\begin{array}{l}\text { UKUPNA PRIPADNOST } \\
\begin{array}{l}\text { ZAJEDNICI } \\
\hline\end{array}\end{array}$ & 65,78 & 0,934 & 2,38 & 2,384 \\
\hline
\end{tabular}

Osim preuzetog instrumenta o pripadnosti zajednici konstruiran je instrument za valorizaciju kulturne baštine. Instrument se sastojao od petnaest tvrdnji na skali slaganja od jedan do pet, a faktorskom analizom $s$ uključenom Varimax rotacijom utvrđena je struktura od četiri faktora (tablica 4, tablica 5). Ukupni koeficijent pouzdanosti Cronbachov alpha iznosi 0,732. Rezultati na podskalama i ukupna valorizacija baštine izračunate su kao prosječan odgovor ispitanika na odgovarajućim česticama (tablica 5).

Tablica 4. Faktorska struktura instrumenta valorizacije kulturne baštine Table 4. Factor structure of the instrument measuring cultural heritage valorisation

\begin{tabular}{rrrr}
\multicolumn{4}{l}{ FAKTORI } \\
\hline 1 & 2 & 3 & 4
\end{tabular}

\section{Faktor 1: Osobni emocionalni odnos prema baštini}

Spomenici na Petrovoj gori vrijedno su kulturno

i povijesno nasljeđe

0,779

Sretan/na sam što spomenici postoje na Petrovoj

gori

0,622

Spomenici podsjećaju na lošu prošlost i zbog

toga ih treba ukloniti

$-0,620$

Ljut/a sam što su spomenici devastirani danas

0,702

\begin{tabular}{ll}
\hline Mišljenja sam kako spomenike treba obnoviti & 0,735 \\
\hline Ljut/a sam što spomenici postoje & $-0,531$
\end{tabular}

Volio/ljela bih kad bi se spomenici iskoristili u

korist zajednice i stanovnika

0,673 


\section{FAKTORI}

$\begin{array}{llll}1 & 2 & 3 & 4\end{array}$

Faktor 2: Ponašajna komponenta valorizacije baštine

Vrlo rijetko obilazim spomenike, jer me ne zanimaju $-0,641$

Vodim prijatelje da vide spomenike i Petrovu goru

Često obilazim spomenike na Petrovoj gori 0,837

Nije mi važno da prijatelji vide spomenike i

Petrovu goru $-0,589$

\section{Faktor 3: Postojanje interesa za spomenike}

Ne zanima me što se događalo kroz povijest sa spomenicima

Mislim kako spomenike treba srušiti, jer ničemu ne služe

0,753

\section{Faktor 4: Značenje spomenika za građane}

Osjećam tjeskobu kad razmišljam o spomenicima 0,726

Spomenici su građanima Vojnića poznati i privlačni

Tablica 5. Pouzdanost i ukupni rezultat na podskalama valorizacije kulturne baštine

Table 5. Reliability and total result of the cultural heritage valorisation subscales

\begin{tabular}{lccccc}
\hline FAKTOR & $\lambda$ & $\begin{array}{c}\text { \% objašnjene } \\
\text { varijance }\end{array}$ & $\begin{array}{c}\text { Cronbachov } \\
\text { alpha }\end{array}$ & M & SD \\
\hline $\begin{array}{l}\text { Faktor 1: Osobni emocionalni } \\
\text { odnos prema baštini }\end{array}$ & 4,80 & 32,03 & 0,804 & 4,68 & 0,428 \\
\hline $\begin{array}{l}\text { Faktor 2: Ponašajna komponenta } \\
\text { valorizacije baštine }\end{array}$ & 1,59 & 10,62 & 0,773 & 4,00 & 0,843 \\
\hline $\begin{array}{l}\text { Faktor 3: Postojanje interesa za } \\
\text { spomenike }\end{array}$ & 1,29 & 8,57 & 0,068 & 4,70 & 0,522 \\
\hline $\begin{array}{l}\text { Faktor 4: Značenje spomenika za } \\
\text { građane }\end{array}$ & 1,11 & 7,42 & 0,041 & 3,68 & 0,895 \\
\hline $\begin{array}{l}\text { UKUPNA VALORIZACIJA } \\
\text { BAŠTINE }\end{array}$ & & 58,64 & 0,732 & 4,37 & 0,409 \\
\hline
\end{tabular}

S obzirom na nisku pouzdanost podskala na faktoru 3 i faktoru 4 , oni nisu uzeti u obzir u daljnjim analizama. 


\section{REZULTATI}

\section{Doživljaj zajednice stanovnika općine Vojnić i razlike s obzirom na sociodemografske karakteristike ispitanika}

Promatrano na razini ukupnog uzorka, ispitanici u prosjeku iskazuju doživljaj zajednice na razini od 2,38 (SD = 0,729, MIN 1; MAX 4), što predstavlja nešto niže vrijednosti, odnosno doživljaj donekle postoji. Najviše prosječne procijenjene dimenzije su na faktoru održavanja kontakata $\mathrm{s}$ članovima zajednice $(\mathrm{M}=2,85 ; \mathrm{SD}=0,87)$, što je vjerojatno rezultat činjenice da je riječ o ruralnom prostoru gdje je običaj da ljudi poznaju svoje susjede. Nešto niži prosječni rezultati dobiveni su na faktorima identificiranja prepoznatljivog identiteta zajednice $(\mathrm{M}=2,5$; $\mathrm{SD}=0,89)$ i pripisivanja emocionalne važnosti pripadnosti zajednici $(\mathrm{M}=2,5$; $\mathrm{SD}=0,98)$. Ovi rezultati vjerojatno proizlaze iz činjenice da se u općini Vojnić dogodila značajna promjena demografske strukture, što za sobom povlači i promjenu ključnih obilježja i doživljaja zajednice, odnosno možemo govoriti o dekonstruiranoj zajednici (Miljenović i Žganec, 2012). Najniže prosječne procjene odnose se na dimenziju utjecaj zajednice na pojedinca i okruženje $(\mathrm{M}=2,12$; $\mathrm{SD}=0,817)$ te vodstvo u zajednici i rješavanje problema $(M=1,91 ; S D=0,866)$. Ovakvi rezultati mogu se tumačiti činjenicom da je Vojnić u prvoj skupini potpomognutih područja, pa je i doživljaj vođenja, rješavanja problema i proaktivnog djelovanja na zajednicu niži.

$S$ obzirom na spol ni u jednoj od dimenzija pripadnosti nisu pronađene statistički značajne razlike, kao ni u ukupnom doživljaju pripadnosti između muškaraca i žena (tablica 6). Ovakav rezultat u skladu je s prethodnom istraživačkom praksom, gdje spolne razlike uglavnom nisu utvrđene.

Tablica 6. Razlike u doživljaju zajednice s obzirom na spol

Table 6. Gender based differences in the assessment of sense of community

\begin{tabular}{lccccc}
\hline \multirow{2}{*}{ DIMENZIJA } & \multicolumn{2}{c}{ MUŠKARCI } & \multicolumn{2}{c}{ ŽENE } & \multirow{2}{*}{ T-test } \\
\cline { 2 - 5 } & $\mathrm{M}$ & $\mathrm{SD}$ & $\mathrm{M}$ & $\mathrm{SD}$ & \\
\hline $\begin{array}{l}\text { Faktor 1: Emocionalna važnost } \\
\text { pripadnosti zajednici }\end{array}$ & 2,49 & 1,010 & 2,50 & 0,956 & $\begin{array}{l}\mathrm{t}=-0,050 \\
\mathrm{df}=98 \\
\mathrm{p}=0,960\end{array}$ \\
\hline $\begin{array}{l}\text { Faktor 2: Prepoznati identitet } \\
\text { zajednice }\end{array}$ & 2,43 & 0,878 & 2,59 & 0,901 & $\begin{array}{l}\mathrm{t}=-1,094 \\
\mathrm{df}=98 \\
\mathrm{p}=0,277\end{array}$ \\
\hline
\end{tabular}




\begin{tabular}{|c|c|c|c|c|c|}
\hline \multirow{2}{*}{ DIMENZIJA } & \multicolumn{2}{|c|}{ MUŠKARCI } & \multicolumn{2}{|c|}{ ŽENE } & \multirow{2}{*}{ T-test } \\
\hline & M & SD & M & SD & \\
\hline $\begin{array}{l}\text { Faktor 3: Utjecaj zajednice na } \\
\text { pojedinca i okruženje }\end{array}$ & 2,07 & 0,814 & 2,18 & 0,824 & $\begin{array}{l}t=-0,780 \\
d f=98 \\
p=0,435\end{array}$ \\
\hline $\begin{array}{l}\text { Faktor } 4 \text { : Vodstvo u zajednici i } \\
\text { rješavanje problema }\end{array}$ & 1,86 & 0,951 & 1,97 & 0,766 & $\begin{array}{l}t=-0,813 \\
d f=98 \\
p=0,418\end{array}$ \\
\hline $\begin{array}{l}\text { Faktor 5: Održavanje kontakata } \\
\text { s članovima zajednice }\end{array}$ & 2,98 & 0,744 & 2,71 & 0,967 & $\begin{array}{l}t=1,895 \\
d f=98 \\
p=0,061\end{array}$ \\
\hline $\begin{array}{l}\text { UKUPNI DOŽIVLJAJ } \\
\text { ZAJEDNICE }\end{array}$ & 2,37 & 0,734 & 2,4 & 0,729 & $\begin{array}{l}t=-0,319 \\
d f=97,46 \\
p=0,750\end{array}$ \\
\hline
\end{tabular}

Što se tiče dobi, koeficijent korelacije upućuje da dob nije statistički značajno povezana s ukupnim doživljajem zajednice $(\mathrm{r}=-0,047)$, s emocionalnom važnošću pripadnosti zajednici $(\mathrm{r}=0,148)$, s prepoznatim identitetom zajednice $(r=-0,096)$, s utjecajem zajednice na pojedinca i okruženje $(r=0,08)$ kao ni s održavanjem kontakata s članovima zajednice $(\mathrm{r}=-0,18)$. Dob se pokazuje statistički značajno povezanom $\mathrm{s}$ doživljajem vodstva u zajednici i rješavanjem problema $(r=-0,21 ; p=0,04)$ na način da mlađi ispitanici iskazuju veći doživljaj vodstva i rješavanja problema u zajednici. Ovakav nalaz donekle iznenađuje s obzirom na to da prethodno prikazana istraživanja višu dob povezuju s višim doživljajem zajednice jer najčešće postoji kontinuitet u dobi i duljini stanovanja. Ovdje zbog zastupljenosti doseljenog stanovništva (nakon sredine devedesetih) u polovini uzorka taj je kontinuitet narušen.

U pogledu razlika s obzirom na nacionalnost, one se pojavljuju u određenim aspektima (tablica 7). U ukupnom doživljaju zajednice razlike nisu statistički značajne, kao ni u faktoru emocionalne važnosti pripadnosti zajednici te doživljaja vodstva u zajednici i rješavanju problema.

Statistički značajne razlike pronađene su na faktoru prepoznatog identiteta zajednice, gdje su procjene ispitanika hrvatske nacionalnosti prosječno više $\mathrm{u}$ odnosu na procjene pripadnika srpske nacionalnosti. Također, ispitanici hrvatske nacionalnosti procjenjuju utjecaj zajednice na pojedinca i okruženje u prosjeku višim, ali s druge strane prosječno imaju manje kontakta $s$ članovima zajednice. 
Tablica 7. Razlike u doživljaju zajednice s obzirom na nacionalnost Table 7. Ethnicity based differences in the assessment of sense of community

\begin{tabular}{|c|c|c|c|c|c|}
\hline \multirow{2}{*}{ DIMENZIJA } & \multicolumn{2}{|c|}{ SRPSKA } & \multicolumn{2}{|c|}{ HRVATSKA } & \multirow{2}{*}{ T-test } \\
\hline & $\mathrm{M}$ & SD & M & SD & \\
\hline $\begin{array}{l}\text { Faktor 1: Emocionalna važnost } \\
\text { pripadnosti zajednici }\end{array}$ & 2,4 & 1,063 & 2,46 & 0,867 & $\begin{array}{l}t=-0,019 \\
d f=91 \\
p=0,985\end{array}$ \\
\hline $\begin{array}{l}\text { Faktor 2: Prepoznati identitet } \\
\text { zajednice }\end{array}$ & 2,32 & 0,995 & 2,70 & 0,675 & $\begin{array}{l}t=-2,660^{* *} \\
d f=89,18 \\
p=0,009\end{array}$ \\
\hline $\begin{array}{l}\text { Faktor 3: Utjecaj zajednice na } \\
\text { pojedinca i okruženje }\end{array}$ & 1,93 & 0,795 & 2,25 & 0,748 & $\begin{array}{l}t=-2,460^{* *} \\
d f=91 \\
p=0,016\end{array}$ \\
\hline $\begin{array}{l}\text { Faktor } 4 \text { : Vodstvo u zajednici i } \\
\text { rješavanje problema }\end{array}$ & 1,8 & 0,945 & 1,99 & 0,784 & $\begin{array}{l}t=-1,357 \\
d f=91 \\
p=0,178\end{array}$ \\
\hline $\begin{array}{l}\text { Faktor 5: Održavanje } \\
\text { kontakata s članovima } \\
\text { zajednice }\end{array}$ & 2,95 & 0,876 & 2,66 & 0,852 & $\begin{array}{l}t=2,050^{* *} \\
d f=91 \\
p=0,043\end{array}$ \\
\hline $\begin{array}{l}\text { UKUPNI DOŽIVLJAJ } \\
\text { ZAJEDNICE }\end{array}$ & 2,29 & 0,792 & 2,43 & 0,630 & $\begin{array}{l}t=-1,182 \\
d f=91 \\
p=0,240\end{array}$ \\
\hline
\end{tabular}

Slične razlike očituju se među ispitanicima s obzirom na to jesu li doseljeni ili su domicilni stanovnici (tablica 8). Na ukupnom doživljaju zajednice statistički značajne razlike su pronađene $u$ tome da $u$ prosjeku nešto više procjene imaju doseljeni stanovnici, što možemo pripisati činjenici da iako je riječ o doseljavanju iz Bosne i Hercegovine, posrijedi je uglavnom hrvatsko stanovništvo kao većinsko i na nacionalnoj razini. S druge strane, domicilno, uglavnom srpsko, stanovništvo svjedočilo je značajnim promjenama strukture stanovništva, a time i zajednice u cjelini. 
Tablica 8. Razlike u doživljaju zajednice s obzirom na doseljenost/domicilno stanovanje

Table 8. Differences in the assessment of sense of community based on the immigration status

\begin{tabular}{|c|c|c|c|c|c|}
\hline \multirow{2}{*}{ DIMENZIJA } & \multicolumn{2}{|c|}{ DOMICILAN } & \multicolumn{2}{|c|}{ DOSELJEN } & \multirow{2}{*}{ T-test } \\
\hline & M & SD & M & SD & \\
\hline $\begin{array}{l}\text { Faktor 1: Emocionalna važnost } \\
\text { pripadnosti zajednici }\end{array}$ & 2,46 & 1,039 & 2,54 & 0,925 & $\begin{array}{l}t=-0,529 \\
d f=98 \\
p=0,598\end{array}$ \\
\hline $\begin{array}{l}\text { Faktor 2: Prepoznati identitet } \\
\text { zajednice }\end{array}$ & 2,35 & 0,991 & 2,67 & 0,733 & $\begin{array}{l}t=-2,275^{* *} \\
d f=90,231 \\
p=0,025\end{array}$ \\
\hline $\begin{array}{l}\text { Faktor 3: Utjecaj zajednice na } \\
\text { pojedinca i okruženje }\end{array}$ & 1,92 & 0,795 & 2,33 & 0,763 & $\begin{array}{l}t=-3,311^{* *} \\
d f=98 \\
p=0,001\end{array}$ \\
\hline $\begin{array}{l}\text { Faktor } 4 \text { : Vodstvo u zajednici i } \\
\text { rješavanje problema }\end{array}$ & 1,75 & 0,894 & 2,06 & 0,798 & $\begin{array}{l}t=-2,301^{* *} \\
d f=98 \\
p=0,024\end{array}$ \\
\hline $\begin{array}{l}\text { Faktor 5: Održavanje kontakata } \\
\text { s članovima zajednice }\end{array}$ & 2,93 & 0,961 & 2,78 & 0,766 & $\begin{array}{l}t=1,093 \\
d f=98 \\
p=0,277\end{array}$ \\
\hline $\begin{array}{l}\text { UKUPNI DOŽIVLJAJ } \\
\text { ZAJEDNICE }\end{array}$ & 2,28 & 0,783 & 2,49 & 0,651 & $\begin{array}{l}t=-1,816^{* *} \\
d f=98 \\
p=0,007\end{array}$ \\
\hline
\end{tabular}

Razlike su uočene i na faktoru prepoznatog identiteta zajednice, pa ga doseljeni stanovnici prosječno procjenjuju u nešto većoj mjeri, prosječno višim ocjenjuju utjecaj zajednice na pojedinca i okruženje te boljim procjenjuju vodstvo i rješavanje problema u zajednici. Statistički značajne razlike između domicilnog i doseljenog stanovništva nisu utvrđene u emocionalnoj važnosti pripadnosti zajednici te održavanju kontakta s članovima zajednice.

Duljina života na području zajednice nije se pokazala povezanom ni s jednom dimenzijom doživljaja zajednice $(\mathrm{r}=0,134$ za faktor $1 ; \mathrm{r}=-0,163$ za faktor $2 ; r=-0,029$ za faktor $3 ; r=-0,149$ za faktor $4 ; r=0,097$ za faktor 5 ) ni $\mathrm{s}$ ukupnim doživljajem pripadnosti $(\mathrm{r}=-0,029)$. Taj nalaz također iznenađuje s obzirom na to da se duljina života najčešće povezuje s višim doživljajem zajednice, no treba ga sagledati u kontekstu dinamike domicilnog i doseljenog stanovništva, pri čemu je doseljeno stanovništvo zapravo na nacionalnoj razini većinsko (iako manjinsko na razini zajednice) te je njiho- 
va integracija amortizirana tom činjenicom i ne može ih se sagledavati kao klasičnu etnički manjinsku skupinu.

Posljednji razlikovni kriterij bilo je obrazovanje ispitanika. Obrazovanje se nije pokazalo povezanim s ukupnim doživljajem zajednice $(\mathrm{r}=0,165)$ ni s većinom dimenzija $(\mathrm{r}=0,17 \mathrm{~s}$ faktorom $1 ; \mathrm{r}=0,108 \mathrm{~s}$ faktorom $2 ; \mathrm{r}=0,144$ $\mathrm{s}$ faktorom $4 ; \mathrm{r}=-0,002 \mathrm{~s}$ faktorom 5$)$. Obrazovanje se pokazalo statistički značajno povezanim jedino s aspektom procjene utjecaja zajednice na pojedinca i okruženje gdje više obrazovani ispitanici višim procjenjuju taj aspekt $(r=0,242 ; p=0,015)$. Budući da literatura daje prednost stanovnicima srednjeg obrazovanja, ovdje je zbog strukture uzorka bilo otežano ispitivanje razlika među skupinama (68\% ima srednju školu, a $27 \%$ više ili visoko obrazovanje).

\section{Valorizacija kulturne baštine Petrove gore na području općine Vojnić i razlike s obzirom na sociodemografske karakteristike ispitanika}

Ukupne prosječne procjene mogućnosti korištenja kulturne baštine na Petrovoj gori visoko su procijenjene, s 4,4, pri čemu je viši emocionalni odnos prema baštini nego ponašajni (tablica 9). Stanovnici vide mogućnost korištenja baštine $u$ raznovrsne svrhe, s iznimkom korištenja $u$ političke, što je razumljivo s aspekta dinamične političke prošlosti ovih prostora. Što se tiče prosječne učestalosti posjećivanja spomenika, ispitanici ih u prosjeku obilaze nekoliko puta godišnje.

Tablica 9. Mogućnosti korištenja i valorizacija kulturne baštine na Petrovoj gori

Table 9. Possibilities of use and valorisation of cultural heritage of Petrova gora

\begin{tabular}{lcccc}
\hline DIMENZIJA & $\begin{array}{c}\text { NAJNIŽI } \\
\text { ODGOVOR }\end{array}$ & $\begin{array}{c}\text { NAJVIŠI } \\
\text { ODGOVOR }\end{array}$ & M & SD \\
\hline UKUPNA VALORIZACIJA & 3,13 & 5,00 & 4,37 & 0,409 \\
\hline $\begin{array}{l}\text { Faktor 1: Osobni emocionalni odnos } \\
\text { prema baštini }\end{array}$ & 3,14 & 5,00 & 4,68 & 0,428 \\
\hline $\begin{array}{l}\text { Faktor 2: Ponašajna komponenta } \\
\text { valorizacije baštine }\end{array}$ & 1,50 & 5,00 & 4,00 & 0,843 \\
\hline $\begin{array}{l}\text { Učestalost obilazaka spomenika na } \\
\text { Petrovoj gori }\end{array}$ & 1,00 & 4,00 & 2,95 & 0,845 \\
\hline $\begin{array}{l}\text { Koliko se spomenici mogu koristiti u: } \\
\text { turističke svrhe }\end{array}$ & 3,00 & 5,00 & 4,77 & 0,548 \\
\hline
\end{tabular}




\begin{tabular}{lcccc}
\hline DIMENZIJA & $\begin{array}{c}\text { NAJNIŽI } \\
\text { ODGOVOR }\end{array}$ & $\begin{array}{c}\text { NAJVIŠI } \\
\text { ODGOVOR }\end{array}$ & M & SD \\
\hline $\begin{array}{l}\text { Koliko se spomenici mogu koristiti u: } \\
\text { umjetničke svrhe }\end{array}$ & 1,00 & 5,00 & 4,44 & 0,808 \\
\hline $\begin{array}{l}\text { Koliko se spomenici mogu koristiti u: } \\
\text { političke svrhe }\end{array}$ & 1,00 & 5,00 & 2,53 & 1,403 \\
$\begin{array}{l}\text { Koliko se spomenici mogu koristiti u: } \\
\text { sportske rekreativne svrhe }\end{array}$ & 1,00 & 5,00 & 4,43 & 0,832 \\
\hline \begin{tabular}{l} 
Ukupna mogućnost korištenja \\
\hline
\end{tabular} & 2,50 & 5,00 & 4,04 & 0,611 \\
\hline
\end{tabular}

Različite ideje o mogućnosti korištenja i valorizaciju kulturne baštine ispitivali smo i s obzirom na sociodemografske karakteristike.

$S$ obzirom na spol utvrđena je tek razlika u učestalosti posjećivanja, gdje žene u prosjeku češće obilaze kulturnu baštinu na Petrovoj gori (tablica 10). No može se uočiti da na svim ostalim razinama žene daju više procjene (izuzev emocionalnog odnosa prema baštini), iako te razlike nisu statistički značajne.

Tablica 10. Razlike u valorizaciji kulturne baštine prema spolu Table 10. Gender based differences in cultural heritage valorisation

\begin{tabular}{|c|c|c|c|c|c|}
\hline \multirow{2}{*}{ Dimenzija valorizacije } & \multicolumn{2}{|c|}{ MUŠKARCI } & \multicolumn{2}{|c|}{ ŽENE } & \multirow{2}{*}{$\begin{array}{l}\text { Rezultati } \\
\text { t-testa }\end{array}$} \\
\hline & $\mathrm{M}$ & SD & M & SD & \\
\hline UKUPNA VALORIZACIJA & 4,36 & 0,41 & 4,37 & 0,412 & $\begin{array}{l}t=-0,065 \\
d f=98 \\
p=0,948\end{array}$ \\
\hline $\begin{array}{l}\text { Faktor 1: Osobni emocionalni } \\
\text { odnos prema baštini }\end{array}$ & 4,71 & 0,356 & 4,65 & 0,496 & $\begin{array}{l}t=0,667 \\
d f=98 \\
p=0,506\end{array}$ \\
\hline $\begin{array}{l}\text { Faktor 2: Ponašajna komponenta } \\
\text { valorizacije baštine }\end{array}$ & 3,96 & 0,908 & 4,04 & 0,775 & $\begin{array}{l}t=-0,442 \\
d f=98 \\
p=0,660\end{array}$ \\
\hline $\begin{array}{l}\text { Učestalost obilazaka spomenika } \\
\text { na Petrovoj gori }\end{array}$ & 2,69 & 0,853 & 3,23 & 0,751 & $\begin{array}{l}t=-3,331^{* * *} \\
d f=98 \\
p=0,001\end{array}$ \\
\hline $\begin{array}{l}\text { Koliko se spomenici mogu } \\
\text { koristiti u: turističke svrhe }\end{array}$ & 4,69 & 0,612 & 4,85 & 0,461 & $\begin{array}{l}t=-1,502 \\
d f=94,310 \\
p=0,137\end{array}$ \\
\hline $\begin{array}{l}\text { Koliko se spomenici mogu } \\
\text { koristiti u: umjetničke svrhe }\end{array}$ & 4,33 & 0,901 & 4,56 & 0,681 & $\begin{array}{l}t=-1,465 \\
d f=98 \\
p=0,146\end{array}$ \\
\hline
\end{tabular}




\begin{tabular}{|c|c|c|c|c|c|}
\hline \multirow{2}{*}{ Dimenzija valorizacije } & \multicolumn{2}{|c|}{ MUŠKARCI } & \multicolumn{2}{|c|}{ ŽENE } & \multirow{2}{*}{$\begin{array}{c}\text { Rezultati } \\
\text { t-testa }\end{array}$} \\
\hline & M & SD & M & SD & \\
\hline $\begin{array}{l}\text { Koliko se spomenici mogu } \\
\text { koristiti u: političke svrhe }\end{array}$ & 2,44 & 1,392 & 2,63 & 1,424 & $\begin{array}{l}t=-0,649 \\
d f=98 \\
p=0,518\end{array}$ \\
\hline $\begin{array}{l}\text { Koliko se spomenici mogu } \\
\text { koristiti u: sportske rekreativne } \\
\text { svrhe }\end{array}$ & 4,33 & 0,857 & 4,54 & 0,798 & $\begin{array}{l}t=-1,294 \\
d f=98 \\
p=0,199\end{array}$ \\
\hline Ukupna mogućnost korištenja & 3,95 & 0,644 & 4,15 & 0,562 & $\begin{array}{l}t=-1,638 \\
d f=98 \\
p=0,105\end{array}$ \\
\hline
\end{tabular}

Nijedna od dimenzija valorizacije kulturne baštine nije povezana s dobi ispitanika, ali neke jesu povezane s obrazovanjem (tablica 11). Obrazovaniji ispitanici prepoznaju u većoj mjeri ukupnu mogućnost korištenja kulturne baštine te specifično u većoj mjeri prepoznaju mogućnosti korištenja u političke svrhe. Među ispitanicima nema bitnijih razlika s obzirom na duljinu stanovanja $\mathrm{u}$ zajednici, te se tek $\mathrm{u}$ mogućnosti korištenja $\mathrm{u}$ sportske svrhe vide razlike u smjeru da ispitanici koji dulje žive u zajednici statistički značajno više uočavaju takvu mogućnost.

Tablica 11. Korelacija valorizacije kulturne baštine s dobi, obrazovanjem i duljinom života u zajednici

Table 11. Correlations between cultural heritage valorisation and age, education and duration of living in the community

\begin{tabular}{lcccc}
\hline & & DOB & OBRAZOVANJE & $\begin{array}{c}\text { DULJINA ŽIVOTA } \\
\text { U ZAJEDNICI }\end{array}$ \\
\hline UKUPNA & $\mathrm{r}$ & 0,010 & 0,080 & 0,095 \\
\cline { 2 - 5 } VALORIZACIJA & $\mathrm{p}$ & 0,925 & 0,427 & 0,349 \\
\cline { 2 - 5 } & $\mathrm{N}$ & 100 & 100 & 100 \\
\hline $\begin{array}{l}\text { Faktor 1: Osobni } \\
\text { emocionalni odnos } \\
\text { prema baštini }\end{array}$ & $\mathrm{r}$ & 0,134 & 0,020 & 0,193 \\
\cline { 2 - 5 } & $\mathrm{p}$ & 0,185 & 0,843 & 0,054 \\
\hline $\begin{array}{l}\text { Faktor 2: Ponašajna } \\
\text { komponenta } \\
\text { valorizacije baštine }\end{array}$ & $\mathrm{r}$ & 100 & 100 & 0,131 \\
\cline { 2 - 5 } & $\mathrm{p}$ & 0,006 & 0,140 & 0,194 \\
\hline
\end{tabular}




\begin{tabular}{|c|c|c|c|c|}
\hline & & DOB & OBRAZOVANJE & $\begin{array}{l}\text { DULJINA ŽIVOTA } \\
\text { U ZAJEDNICI }\end{array}$ \\
\hline \multirow{3}{*}{$\begin{array}{l}\text { Ukupna mogućnost } \\
\text { korištenja }\end{array}$} & $\mathrm{r}$ & 0,084 & $0,202^{* *}$ & 0,180 \\
\hline & $\mathrm{p}$ & 0,408 & 0,043 & 0,073 \\
\hline & $\mathrm{N}$ & 100 & 100 & 100 \\
\hline \multirow{3}{*}{$\begin{array}{l}\text { Koliko se spomenici } \\
\text { mogu koristiti u: } \\
\text { turističke svrhe }\end{array}$} & $\mathrm{r}$ & $-0,086$ & 0,048 & 0,098 \\
\hline & $\mathrm{p}$ & 0,397 & 0,634 & 0,330 \\
\hline & $\mathrm{N}$ & 100 & 100 & 100 \\
\hline \multirow{3}{*}{$\begin{array}{l}\text { Koliko se spomenici } \\
\text { mogu koristiti u: } \\
\text { umjetničke svrhe }\end{array}$} & $\mathrm{r}$ & 0,075 & 0,095 & 0,189 \\
\hline & $\mathrm{p}$ & 0,460 & 0,346 & 0,059 \\
\hline & $\mathrm{N}$ & 100 & 100 & 100 \\
\hline \multirow{3}{*}{$\begin{array}{l}\text { Koliko se spomenici } \\
\text { mogu koristiti u: } \\
\text { političke svrhe }\end{array}$} & $\mathrm{r}$ & 0,056 & $0,221^{* *}$ & 0,035 \\
\hline & $\mathrm{p}$ & 0,582 & 0,027 & 0,731 \\
\hline & $\mathrm{N}$ & 100 & 100 & 100 \\
\hline \multirow{3}{*}{$\begin{array}{l}\text { Koliko se spomenici } \\
\text { mogu koristiti u: } \\
\text { sportske rekreativne } \\
\text { svrhe }\end{array}$} & $\mathrm{r}$ & 0,136 & 0,098 & $0,222^{* *}$ \\
\hline & $\mathrm{p}$ & 0,178 & 0,331 & 0,026 \\
\hline & $\mathrm{N}$ & 100 & 100 & 100 \\
\hline \multirow{3}{*}{$\begin{array}{l}\text { Učestalost obilazaka } \\
\text { spomenika na Petrovoj } \\
\text { gori }\end{array}$} & $\mathrm{r}$ & 0,123 & $-0,156$ & $-0,120$ \\
\hline & $\mathrm{p}$ & 0,224 & 0,120 & 0,233 \\
\hline & $\mathrm{N}$ & 100 & 100 & 100 \\
\hline
\end{tabular}

U posljednjem segmentu ispitivali smo razlike u valorizaciji kulturne baštine među ispitanicima različite nacionalnosti i s obzirom na to jesu li domicilni stanovnici ili su se doselili u zajednicu.

Tablica 12. Mogućnosti korištenja i valorizacija kulturne baštine s obzirom na nacionalnost

Table 12. Possibilities of use and cultural heritage valorisation in regard to ethnic affiliation

\begin{tabular}{|c|c|c|c|c|c|}
\hline \multirow{2}{*}{ Dimenzija valorizacije } & \multicolumn{2}{|c|}{$\begin{array}{c}\text { SRPSKA } \\
\text { NACIONALNOST }\end{array}$} & \multicolumn{2}{|c|}{$\begin{array}{c}\text { HRVATSKA } \\
\text { NACIONALNOST }\end{array}$} & \multirow{2}{*}{$\begin{array}{c}\text { Rezultati } \\
\text { t-testa }\end{array}$} \\
\hline & $\mathrm{M}$ & SD & $\mathrm{M}$ & SD & \\
\hline UKUPNA VALORIZACIJA & 4,48 & 0,295 & 4,21 & 0,454 & $\begin{array}{l}\mathrm{t}=3,249^{* *} \\
\mathrm{df}=65,336 \\
\mathrm{p}=0,002\end{array}$ \\
\hline $\begin{array}{l}\text { Faktor 1: Osobni emocionalni } \\
\text { odnos prema baštini }\end{array}$ & 4,84 & 0,278 & 4,49 & 0,502 & $\begin{array}{l}\mathrm{t}=3,998^{* * *} \\
\mathrm{df}=58,988 \\
\mathrm{p}=0,000\end{array}$ \\
\hline
\end{tabular}




\begin{tabular}{|c|c|c|c|c|c|}
\hline \multirow{2}{*}{ Dimenzija valorizacije } & \multicolumn{2}{|c|}{$\begin{array}{c}\text { SRPSKA } \\
\text { NACIONALNOST }\end{array}$} & \multicolumn{2}{|c|}{$\begin{array}{c}\text { HRVATSKA } \\
\text { NACIONALNOST }\end{array}$} & \multirow{2}{*}{$\begin{array}{c}\text { Rezultati } \\
\text { t-testa }\end{array}$} \\
\hline & $\mathrm{M}$ & SD & M & SD & \\
\hline $\begin{array}{l}\text { Faktor 2: Ponašajna komponenta } \\
\text { valorizacije baštine }\end{array}$ & 4,22 & 0,787 & 3,68 & 0,825 & $\begin{array}{l}t=3,205^{* * *} \\
d f=91 \\
p=0,002\end{array}$ \\
\hline $\begin{array}{l}\text { Učestalost obilazaka spomenika } \\
\text { na Petrovoj gori }\end{array}$ & 2,87 & 0,742 & 3,17 & 0,863 & $\begin{array}{l}t=-1,833 \\
d f=91 \\
p=0,070\end{array}$ \\
\hline $\begin{array}{l}\text { Koliko se spomenici mogu } \\
\text { koristiti u: turističke svrhe }\end{array}$ & 4,88 & 0,427 & 4,63 & 0,623 & $\begin{array}{l}t=2,199^{* *} \\
d f=67,863 \\
p=0,031\end{array}$ \\
\hline $\begin{array}{l}\text { Koliko se spomenici mogu } \\
\text { koristiti u: umjetničke svrhe }\end{array}$ & 4,69 & 0,612 & 4,17 & 0,919 & $\begin{array}{l}t=3,128^{* *} \\
d f=66,443 \\
p=0,003\end{array}$ \\
\hline $\begin{array}{l}\text { Koliko se spomenici mogu } \\
\text { koristiti u: političke svrhe }\end{array}$ & 2,37 & 1,469 & 2,71 & 1,346 & $\begin{array}{l}t=-1,156 \\
d f=91 \\
p=0,251\end{array}$ \\
\hline $\begin{array}{l}\text { Koliko se spomenici mogu } \\
\text { koristiti u: sportske rekreativne } \\
\text { svrhe }\end{array}$ & 4,58 & 0,871 & 4,29 & 0,750 & $\begin{array}{l}t=1,660 \\
d f=91 \\
p=0,100\end{array}$ \\
\hline Ukupna mogućnost korištenja & 4,13 & 0,574 & 3,95 & 0,648 & $\begin{array}{l}t=1,407 \\
d f=91 \\
p=0,163\end{array}$ \\
\hline
\end{tabular}

Očekivano, u mnogim aspektima postoje statistički značajne razlike u valorizaciji i mogućnostima korištenja. Ispitanici srpske nacionalnosti u prosjeku iskazuju u većoj mjeri valorizaciju baštine, imaju više prosječne procjene osobnoga emocionalnog odnosa prema baštini, ponašanjem iskazuju valorizaciju baštine te $u$ prosjeku vide veće mogućnosti korištenja baštine u turističke i umjetničke svrhe. U pogledu učestalosti obilazaka, ukupne procjene mogućnosti korištenja i specifične procjene mogućnosti korištenja u sportske i političke svrhe nisu nađene statistički značajne razlike među ispitanicima.

Slični su rezultati dobiveni u vezi s razlikama među ispitanicima s obzirom na to jesu li doseljeni ili domicilni stanovnici (tablica 13). 
Tablica 13. Mogućnosti korištenja i valorizacija kulturne baštine s obzirom na to je li ispitanik domicilan ili doseljen stanovnik

Table 13. Possibilities of use and cultural heritage valorisation in regard to immigration status

\begin{tabular}{|c|c|c|c|c|c|}
\hline \multirow{2}{*}{ Dimenzija valorizacije } & \multicolumn{2}{|c|}{$\begin{array}{l}\text { DOMICILAN } \\
\text { STANOVNIK }\end{array}$} & \multicolumn{2}{|c|}{$\begin{array}{l}\text { DOSELJEN } \\
\text { STANOVNIK }\end{array}$} & \multirow{2}{*}{$\begin{array}{c}\text { Rezultati } \\
\text { t-testa }\end{array}$} \\
\hline & $\mathrm{M}$ & $\mathrm{SD}$ & $\mathrm{M}$ & SD & \\
\hline UKUPNA VALORIZACIJA & 4,45 & 0,302 & 4,29 & 0,484 & $\begin{array}{l}t=1,952 \\
d f=82,104 \\
p=0,054\end{array}$ \\
\hline $\begin{array}{l}\text { Faktor 1: Osobni emocionalni } \\
\text { odnos prema baštini }\end{array}$ & 4,8 & 0,331 & 4,55 & 0,477 & $\begin{array}{l}t=3,024^{* *} \\
d f=87,330 \\
p=0,003\end{array}$ \\
\hline $\begin{array}{l}\text { Faktor 2: Ponašajna } \\
\text { komponenta valorizacije } \\
\text { baštine }\end{array}$ & 4,18 & 0,823 & 3,82 & 0,835 & $\begin{array}{l}t=2,142^{* *} \\
d f=98 \\
p=0,035\end{array}$ \\
\hline $\begin{array}{l}\text { Učestalost obilazaka } \\
\text { spomenika na Petrovoj gori }\end{array}$ & 2,84 & 0,681 & 3,06 & 0,978 & $\begin{array}{l}t=-1,306 \\
d f=87,492 \\
p=0,195\end{array}$ \\
\hline $\begin{array}{l}\text { Koliko se spomenici mogu } \\
\text { koristiti u: turističke svrhe }\end{array}$ & 4,88 & 0,435 & 4,66 & 0,626 & $\begin{array}{l}t=2,040^{* *} \\
d f=87,372 \\
p=0,044\end{array}$ \\
\hline $\begin{array}{l}\text { Koliko se spomenici mogu } \\
\text { koristiti u: umjetničke svrhe }\end{array}$ & 4,72 & 0,573 & 4,16 & 0,912 & $\begin{array}{l}t=3,678^{* * *} \\
d f=82,479 \\
p=0,000\end{array}$ \\
\hline $\begin{array}{l}\text { Koliko se spomenici mogu } \\
\text { koristiti u: političke svrhe }\end{array}$ & 2,52 & 1,542 & 2,54 & 1,265 & $\begin{array}{l}t=-0,071 \\
d f=94,400 \\
p=0,944\end{array}$ \\
\hline $\begin{array}{l}\text { Koliko se spomenici mogu } \\
\text { koristiti u: sportske rekreativne } \\
\text { svrhe }\end{array}$ & 4,68 & 0,683 & 4,18 & 0,896 & $\begin{array}{l}t=3,137^{* *} \\
d f=98 \\
p=0,002\end{array}$ \\
\hline Ukupna mogućnost korištenja & 4,2 & 0,565 & 3,89 & 0,621 & $\begin{array}{l}t=2,653^{* *} \\
d f=98 \\
p=0,009\end{array}$ \\
\hline
\end{tabular}

Očekivano i u skladu s razlikama dobivenima za nacionalnost, domicilni stanovnici u više aspekata procjenjuju mogućnosti korištenja baštine, odnosno daju više prosječne procjene valorizacije baštine. To se specifično odnosi na prosječno izraženiji osobni emocionalni odnos prema baštini, izraženije valoriziranje baštine svojim ponašanjem te uočene veće mogućnosti korištenja baštine uopće, a specifično u turističke, umjetničke i sportsko-rekreativne svrhe. U pogledu procjene učestalosti posjećivanja spomenika nema 
statistički značajnih razlika, kao ni u pogledu procjene mogućnosti njihova korištenja u političke svrhe.

\section{Povezanost dimenzija doživljaja zajednice i valorizacije kulturne baštine na području Petrove gore}

U kontekstu razvoja zajednice kao procesa iznimno je važno sagledati povezanost prepoznavanja lokalnih resursa, što $u$ ovom slučaju predstavlja kulturna baština, te sam odnos prema zajednici, što smo prethodno mjerili upitnikom doživljaja zajednice.

Pronađene su poneke statistički značajne povezanosti (tablica 14), i to na način da je utvrđeno da oni ispitanici koji pridaju veću emocionalnu važnost doživljaju pripadnosti te koji održavaju više kontakata s članovima zajednice ukupno više valoriziraju baštinu te također više iskazuju na faktoru ponašajne valorizacije. Spomenike češće obilaze oni ispitanici koji imaju više kontakata s drugim članovima zajednice. Zapravo se održavanje kontakata s drugim članovima zajednice pokazuje ključnim za valorizaciju kulturne baštine u svim dimenzijama. Zanimljivo je da nema statistički značajne povezanosti između doživljaja pripadnosti i procijenjene mogućnosti korištenja, što nas dovodi do zaključka da, unatoč doživljaju pripadnosti, ispitanici su uglavnom složni oko visokih procjena mogućnosti korištenja u različite svrhe (s izuzetkom mogućnosti korištenja u političke svrhe, koja je nisko procijenjena).

Tablica 14. Povezanost faktora doživljaja zajednice i valorizacije kulturne baštine

Table 14. Correlation between factors of the assessment of sense of community and cultural heritage valorisation

\begin{tabular}{lcccc}
\hline & $\begin{array}{c}\text { Ukupna } \\
\text { Valorizacija }\end{array}$ & $\begin{array}{c}\text { F1: Osobni } \\
\text { emocionalni } \\
\text { odnos prema } \\
\text { baštini }\end{array}$ & $\begin{array}{c}\text { F2: Ponašajna } \\
\text { komponenta } \\
\text { valorizacije } \\
\text { baštine }\end{array}$ & $\begin{array}{c}\text { Čestina } \\
\text { obilazaka } \\
\text { spomenika }\end{array}$ \\
\hline $\begin{array}{l}\text { Faktor 1: Emocionalna } \\
\text { važnost pripadnosti zajednici }\end{array}$ & $\mathbf{0 , 2 2 0 ^ { * }}$ & 0,104 & $\mathbf{0 , 2 5 3 ^ { * }}$ & $-0,085$ \\
\hline $\begin{array}{l}\text { Faktor 2: Prepoznati identitet } \\
\text { zajednice }\end{array}$ & 0,092 & $-0,010$ & 0,088 & $-0,020$ \\
\hline $\begin{array}{l}\text { Faktor 3: Utjecaj zajednice na } \\
\text { pojedinca i okruženje }\end{array}$ & 0,070 & $-0,059$ & 0,092 & $-0,063$ \\
\hline $\begin{array}{l}\text { Faktor 4: Vodstvo u zajednici } \\
\text { i rješavanje problema }\end{array}$ & 0,132 & 0,014 & 0,134 & $-0,063$ \\
\hline
\end{tabular}




\begin{tabular}{lcccc}
\hline & $\begin{array}{c}\text { Ukupna } \\
\text { Valorizacija }\end{array}$ & $\begin{array}{c}\text { F1: Osobni } \\
\text { emocionalni } \\
\text { odnos prema } \\
\text { baštini }\end{array}$ & $\begin{array}{c}\text { F2: Ponašajna } \\
\text { komponenta } \\
\text { valorizacije } \\
\text { baštine }\end{array}$ & $\begin{array}{c}\text { Čestina } \\
\text { obilazaka } \\
\text { spomenika }\end{array}$ \\
\hline $\begin{array}{l}\text { Faktor 5: Održavanje } \\
\text { kontakata s članovima } \\
\text { zajednice }\end{array}$ & $\mathbf{0 , 3 1 3 ^ { * * }}$ & $\mathbf{0 , 2 0 6 ^ { * }}$ & $\mathbf{0 , 2 7 9 ^ { * * }}$ & $\mathbf{- 0 , 2 6 ^ { * * }}$ \\
\hline $\begin{array}{l}\text { UKUPNI DOŽIVLJAJ } \\
\text { ZAJEDNICE }\end{array}$ & 0,195 & 0,056 & $\mathbf{0 , 2 0 2 ^ { * }}$ & $-\mathbf{0 , 1 0 9}$ \\
\hline
\end{tabular}

** Značajnost povezanosti na razini 0,$01 ;{ }^{*}$ Značajnost povezanosti na razini 0,05

\section{RASPRAVA I ZAKLJUČAK}

Doživljaj zajednice preduvjet je stvaranja lokalnog identiteta, a proizlazi iz blizine stanovnika onome što se $\mathrm{u}$ zajednici događa te stvaranja uvida $\mathrm{u}$ osobitosti i potencijale zajednice. Kada se pojavljuju razlike u zajednici, poput etničkih, one su izazov za doživljaj zajednice te otvaraju potrebu za ponovnom konstrukcijom identiteta. Baština predstavlja vidljiva obilježja zajednice, u sebi čuva kolektivnu memoriju i daje svojevrstan duh zajednici bivajući medij kroz koji sadašnji način razmišljanja i potrebe stanovnika komuniciraju s prošlosti zajednice. Slijedom toga baština igra važnu ulogu u stvaranju doživljaja zajednice, odnosno u procesu izgradnje ili redefiniranja identiteta zajednice. U ovom istraživanju, gledajući razlike među stanovnicima u doživljaju zajednice i valorizaciji baštine Petrove gore, možemo zaključiti sljedeće:

a) Suprotno spoznajama prethodnih istraživanja, u ovom je istraživanju doživljaj zajednice odvojen od činjenice je li stanovnik domicilan, koliko dugo živi u zajednici i pripada li etničkoj grupi koja je većinska u zajednici. Dapače, doseljeno stanovništvo, uglavnom hrvatske nacionalnosti, s kraćim životom u zajednici, iskazuje viši doživljaj zajednice u različitim dimenzijama. Možemo pretpostaviti da je njihov doživljaj zajednice osnažen činjenicom da je hrvatsko stanovništvo većinsko na nacionalnoj razini te se etnički odnosi na sličan način prelijevaju na lokalnu razinu.

b) S druge strane, rezultati pokazuju da domicilno stanovništvo, uglavnom srpske nacionalnosti, s duljim životom u zajednici, više valorizira baštinu Petrove gore, koja je jedan od najpoznatijih simbola zajednice.

c) Neovisno o etničkoj pripadnosti, na razini cijelog uzorka stanovnici u prosjeku više valoriziraju kulturnu baštinu nego što iskazuju doživljaj zajednice. Također neovisno o etničkoj pripadnosti, oni stanovnici kojima pri- 
padnost zajednici više znači, koji imaju više kontakta s drugima i koji imaju općenito veći doživljaj zajednice pozitivnije su orijentirani prema baštini, bilo na emocionalnoj, bilo na ponašajnoj razini.

Ovi rezultati upućuju na to da je vrednovanje baštine odvojeno ili dezintegrirano od lokalnog identiteta (što se posebice vidi kada sagledavamo različite procjene etničkih skupina). Ipak, kako identitet nije statičan koncept te ga možemo smatrati i procesom i ishodom dinamike $u$ zajednici, vidimo mogućnosti da se baština snažnije počne konstruirati kao identitetski element. Ako stanovništvo sudjeluje u kulturnim aktivnostima, ono stvara memoriju povezanu s baštinom na individualnoj razini koja se tada približava kolektivnom shvaćanju. Tome pridonose i edukacije s posebnim naglaskom na mlade i stanovnike srednje stručne spreme. Naime mladi $\mathrm{u}$ životnoj tranziciji nakon završetka srednje škole dolaze u razdoblje kada će se njihov doživljaj zajednice smanjiti ako ih se aktivno ne uključi u život zajednice, pa i korištenje i vrednovanje baštine. Stanovnici sa srednjom stručnom spremom u prethodnim se istraživanjima potvrđuju kao oni na kojima ostaje budućnost zajednice, posebice ako je riječ o ruralnim i rjeđe naseljenim područjima. $U$ ovom istraživanju značajnijih razlika nema s obzirom na obrazovanje ispitanika, no to bi trebalo dodatno istražiti imajući u vidu ograničenja uzorka i nedovoljnu zastupljenost različitih obrazovnih skupina. Visokoobrazovani ispitanici iskazali su šire mogućnosti korištenja baštine Petrove gore $u$ političke svrhe, dok je na razini cijelog uzorka ta mogućnost dosta nisko procijenjena, pa i tabuizirana. No ako se politika poima u kontekstu demokratizacije i razvoja aktivnoga građanstva, tada bi se moglo više otvoriti i prema ovim mogućnostima.

Rezultati istraživanja upućuju da etnička podjela definirana na nacionalnoj razini još uvijek priječi doživljaj zajednice i izgradnju lokalnog identiteta. No etnički identiteti imaju manji utjecaj na viđenje baštine, što stvara priliku da se tradicionalno čvrste granice među grupama učine labavijima, pa i premoste. Globalne i lokalne silnice u današnjem vremenu snažno utječu na (re)definiranje, pa i slabljenje granica među etničkim skupinama (Wimmer, 2008). Ako uzmemo da granice nisu prirodna danost, već rezultat društvene institucionalizacije, tada se one u društvenim procesima mogu i redefinirati (Brubaker, 2012). Brojni su načini na koje se granice etničkih skupina nadilaze ili zamagljuju (Wimmer, 2008). Više skupina može postati dijelom šire socijalne sfere, ali se etnički identitet može redefinirati i na užoj lokalnoj razini, kao što neki drugi kriterij može postati odrednicom identiteta. Novi lokalni identitet, koji se dijelom temelji na pozitivnom vrednovanju 
baštine, može za nove generacije biti čimbenik premošćivanja granica etničkih skupina. Do toga mogu dovesti i nadnacionalni čimbenici, kao što je život u socijalnom prostoru Europske unije ili intenzivna migracijska kretanja posljednjih godina. Da bi stanovnici ovog područja pronašli zajedničku osnovu pripadnosti zajednici kao preduvjet njezina budućeg razvoja, važno je premostiti granice etničkog identiteta, posebice kada one postaju čimbenikom isključivanja (Mlinarić i Gregurović, 2018). To ne znači negaciju etničke pripadnosti, već stvaranje takva ozračja u kojem se nadilazi razgraničenje »nas od njih« (Mlinarić i Gregurović, 2018).

Kao jedno od ograničenja istraživanja vidimo činjenicu da je riječ o malom i prigodnom uzorku te kontaktiranju ispitanika metodom snježne grude počevši od kruga osoba poznatih istraživačici, iz čega proizlaze i određene pristranosti. No u Hrvatskoj se dosad nije primijenio indeks doživljaja zajednice na primjeru jedne lokalne zajednice, te ovo smatramo važnim metodološkim doprinosom. Mislimo da je važno nastaviti proučavati odnos doživljaja zajednice, pripadnosti zajednici i lokalnog identiteta prema valorizaciji kulturne baštine te ove teme staviti u kontekst ekonomskog osnaživanja zajednice, demografske obnove i smanjenja regionalnih nejednakosti.

\section{LITERATURA}

Babić, D., Vatan Kaptan, M. i Masriera Esquerra, C. (2019). Heritage Literacy: A Model to Engage Citizens in Heritage Management, u: M. Obad Šćitaroci, B. Bojanić Obad Šćitaroci, i A. Mrđa (ur.). Cultural Urban Heritage. Development, Learning and Landscape Strategies. Cham: Springer, 1-18.

Barbieri, I. i Zani, B. (2015). Multiple Sense of Community, Identity, and Well-Being in a Context of Multi Culture: a Mediation Model, Community Psychology in Global Perspective, 1 (2): 40-60, doi: https://doi.org/10.1285/i24212113v1i2p40

Brubaker, R. (2012). Promišljanje nacionalnosti: Nacija kao institucionalizirani obrazac, praktička kategorija, uvjetovani događaj, Diskrepancija, 11 (16/17): 107-117.

Castellini, F., Colombo, M., Maffeis, D. i Montali, L. (2011). Sense of community and interethnic relations: Comparing local communities varying in ethnic heterogeneity, Journal of Community Psychology, 39 (6): 663-677, doi: https://doi.org/10.1002/ jcop.20459

Chavis, D. M., Lee, K. S. i Acosta J. D. (2008). The Sense of Community (SCI) Revised: The Reliability and Validity of the SCI-2, 2nd International Community Psychology Conference, Lisbon, 4. - 6. lipnja 2008.

Državni zavod za statistiku (2011). Osobna potrošnja i pokazatelji siromaštva. Državni zavod za statistiku, travanj 2019., https://www.dzs.hr/Hrv/DBHomepages/ Osobna\%20potrosnja\%20i\%20pokazatelji\%20siromastva/Metodologija_HBS_ WB.pdf 
Evans, S. D. (2007). Youth sense of community: Voice and power in community contexts, Journal of Community Psychology, 35 (6): 693-709, doi: https://doi.org/10.1002/ jcop. 20173

Farahani, L. M. (2016). The Value of the Sense of Community and Neighbouring, Housing, Theory and Society, 33 (3): 357-376, doi: https://doi.org/10.1080/14036096.2016.1155480

French, S., Wood, L., Foster, S. A., Giles-Corti, B., Frank, L. i Learnihan, V. (2014). Sense of Community and Its Association With the Neighborhood Built Environment, Environment and Behavior, 46 (6), 677-697, doi: https://doi. org/10.1177/0013916512469098

Gattino, S., Piccoli, N., Fassio, O. i Rollero, C. (2013). Quality of life and sense of community. A study on health and place of residence, Journal of Community Psychology, 41 (7): 811-826, doi: https://doi.org/10.1002/jcop.21575

Gueorguiev, S. D., Gómez, E. i Hill, E. (2007). Public Recreation and Neighborhood Sense of Community: an Exploration of a Hypothesized Relationship, u: Cherie LeBlanc i Christine Vogt (ur.). Proceedings of the 2007 Northeastern Recreation Research Symposium. Newtown Square: U.S. Forest Service, Northern Research Station, 198202.

Harrill, R. (2004). Residents' attitudes toward tourism development: A literature review with implications for tourism planning, Journal of Planning Literature, 18 (3): 251-266, doi: https://doi.org/10.1177/0885412203260306

Hombrados-Mendieta, I., Gómez-Jacinto, L. i Dominguez-Fuentes, J. M. (2009). The impact of immigrants on the sense of community, Journal of Community Psychology, 37 (6): 671-683, doi: https://doi.org/10.1002/jcop.20323

Lardier, D. T. (2018). An examination of ethnic identity as a mediator of the effects of community participation and neighborhood sense of community on psychological empowerment among urban youth of color, Journal of Community Psychology, 46 (5): 551-566, doi: https://doi.org/10.1002/jcop.21958

Long, D. A. i Perkins, D. D. (2007). Community social and place predictors of sense of community: A multilevel and longitudinal analysis, Journal of Community Psychology, 35 (5): 563-581, doi: https://doi.org/10.1002/jcop.20165

Mannarini, T. i Fedi, A. (2009). Multiple senses of community: The experience and meaning of community, Journal of Community Psychology, 37 (2): 211-227, doi: https:// doi.org/10.1002/jcop.20289

McMillan, D. W. i Chavis, D. M. (1986). Sense of community: A definition and theory. Special Issue: Psychological sense of community: Theory and concepts, Journal of Community Psychology, 14 (1): 6-23, doi: https://doi.org/10.1002/15206629(198601)14:1<6::AID-JCOP2290140103>3.0.CO;2-I

Miljenović, A. i Žganec, N. (2012). Disintegration and possibilities for rebuilding of waraffected communities: The Vojnić Municipality case, International Social Work, 55 (5): 645-661, doi: https://doi.org/10.1177/0020872812447636

Mlinarić, D. i Gregurović, S. (2018). Prilog promišljanju oblikovanja hrvatskih granica u povijesnoj i suvremenoj perspektivi, Geoadria, 23 (2): 153-175, doi: https://doi. org/10.15291/geoadria.1506

Obst, P., Smith, S. G. i Zinkiewicz, L. (2002). An Exploration of Sense of Community, Part 3: Dimensions and Predictors of Psychological Sense of Community in Geographical Communities, Journal of Community Psychology, 30 (1): 119-133, doi: https://doi. org/10.1002/jcop.1054 
Opačić, V. T. (2019). Tourism Valorization of Cultural Heritage, u: M. Obad Šćitaroci, B. Bojanić Obad Šćitaroci i A. Mrđa (ur.). Cultural Urban Heritage. Development, Learning and Landscape Strategies. Cham: Springer, 181-196.

Pampalon, R., Hamel, D., De Koninck, M. i Disant, M. J. (2007). Perception of place and health: Differences between neighbourhoods in the Québec City region, Social Science and Medicine, 65 (1): 95-111, doi: https://doi.org/10.1016/j.socscimed.2007.02.044

Perkins, D. D. i Long, D. A. (2011). Neighborhood Sense of Community and Social Capital, u: A. T. Fisher, C. C. Sonn, B. J. Bishop (ur.). Psychological Sense of Community: Research, Applications, and Implications. New York: Springer, 291-318, doi: https://doi. org/10.1007/978-1-4615-0719-2_15

Pretty, G., Bishop, B., Fisher, A. i Sonn, C. (2006) Psychological sense of community and its relevance to well-being and everyday life in Australia: a position paper of the Australian Psychological Society. Technical Report. Melbourne: Australian Psychological Society,

Prezza, M. i Pacilli, M. G. (2007). Current fear of crime, sense of community and loneliness in Italian adolescents: The role of autonomous mobility and play during childhood, Journal of Community Psychology, 35 (2): 151-170, doi: http://dx.doi.org/10.1002/ jcop. 20140

Prezza, M., Pacilli, M. G., Barbaranelli, C. i Zampatti, E. (2009). The MTSOCS: A multidimensional sense of community scale for local communities, Journal of Community Psychology, 37 (3): 305-326, doi: https://doi.org/10.1002/jcop.20297

Reeves, K. i Plets, G. (2016). Cultural Heritage as a Strategy for Social Needs and Community Identity, u: W. Logan, M. Nic Craith i U. Kockel (ur.). A Companion to Heritage Studies. Malden: John Wiley \& Sons, 203-214.

Rubić, T. (2005). Pitanja i razine identiteta na primjeru kulturno umjetničkih društava na Kordunu, Etnološka tribina, 34/35 (27-28): 111-146.

Schuster, R. M., Sullivan, L. E., Kuehn, D. M. i Morais, D. B. (2011). Relationships among Resident Participation in Nature and Heritage Tourism Activities, Place Attachment, and Sustainability in three Hudson River Valley Communities, Journal of Park and Recreation Administration, 29 (3): 55-69.

Škiljan, F. (2007). Kulturno-historijski spomenici Korduna. Zagreb: Srpsko narodno vijeće.

Šošić, M. T. (2014). Pojam kulturne baštine - međunarodno pravni pogled, Zbornik radova Pravnog fakulteta u Splitu, 4 (51): 833-860.

Theodori, A. E. i Theodori, G. L. (2015). The influences of community attachment, sense of community, and educational aspirations upon the migration intentions of rural youth in Texas, Community Development, 46 (4): 380-391, doi: https://doi.org/10.1080 /15575330.2015.1062035

Wimmer, A. (2008). The Making and Unmaking of Ethnic Boundaries: A Multilevel Process Theory, American Journal of Sociology, 113 (4): 970-1022, doi: https://doi. org/10.1086/522803

Zakon o područjima posebne državne skrbi, Narodne novine, 86/08, 57/11, 51/13, 148/13, 76/14, 147/14, 18/15, 106/18.

Zatezalo, Đ. (2010). Petrova gora, uloga i značaj u NOR-u Hrvatske 1941.-1945. Zagreb: Srpsko narodno vijeće. 


\title{
IZVORI
}

Popis stanovništva, domaćinstava, stanova i poljoprivrednih gospodarstava 1991., Stanovništvo prema migracijskim obilježjima, Državni zavod za statistiku, Zagreb.

Popis stanovništva, kućanstava i stanova 2001., Državni zavod za statistiku, Zagreb, www. dzs.hr.

Popis stanovništva, kućanstva i stanova 2011., Državni zavod za statistiku, Zagreb, www. dzs.hr.

\section{Perception of Community and Relationship to Cultural Heritage from the Perspective of Two Ethnic Groups: The Example of the Vojnić Municipality}

\author{
Natalija Oparnica, Ana Opačić
}

\begin{abstract}
SUMMARY
This paper focusses on the concepts of sense of community and the valorisation of cultural heritage through the example of one Croatian municipality. This municipality is multi-ethnic, it deals with developmental challenges, and has a famous cultural heritage of significant artistic, historical and symbolic value beyond the local level. The paper aimed at exploring how these concepts differ regarding the socio-demographic characteristics of its habitants, and how they correlate with each other.
\end{abstract}

The sense of community is an important element in community processes, being a prerequisite of social capital, community attachment and constructed local identity. The phrase "sense of community" is used according to McMillan and Chavis (1986) and their definition which includes four elements: membership (feeling of belonging or sharing personal relatedness), influence (the sense that the group matters to the individual and vice versa), integration and fulfilment of needs (living in a community means benefits with regard to living standards and that habitants value reciprocity) and shared emotional connections (members believe that they share history, experiences, common symbols). Research on the sense of community suggests that it derives both from individual and contextual factors. Members with a higher sense of community are older residents, those who have lived in the community for a longer period of time, retired people, residents with secondary education, residents with children and those who live with a partner, as well as members who are active in local groups, spend more time in outdoor community space, those more willing to have active social relationships with their neighbours and informal social control, and those with a stronger place attachment. A higher sense of community is also found in residents that envision their community as broader than a street/block, those that believe that a community can achieve goals and that community, as a value, is important to them. Contextual predictors of a sense of community are collective efficacy, citizens' participation, place attachment. A higher sense of community exists in rural communities and communities with a lower population density. Ethnic heterogeneity is usually connected with a lower sense of community. However, 
some authors find that ethnic heterogeneity is indirectly connected with the sense of community through lower income, which is often the case in multi-ethnic communities. A sense of community has many positive individual and collective effects, e.g. higher level of interpersonal trust, wellbeing, quality of life, mental and physical health, willingness to remain a part of the community, stronger social capital.

Cultural heritage enables community connections with the past and the present while community identity is negotiated between present needs and viewpoints and what is considered important for the past of the community. Cultural heritage archives collective memory and often becomes important when group relations should be redefined. Thus, heritage can be a factor of cohesion, confidence, provide legitimacy for community interests, but it can also become a point of dispute, a source of political and social conflict. Residents' connection to their heritage plays a crucial role in this dynamic between heritage and identity, specifically how they value and think of heritage on an emotional and behavioural level.

This paper is focussed specifically on the heritage of the Petrova gora area in Vojnic municipality, with the two most prominent heritage sites being the monument dedicated to antifascist struggles and partisans by sculptor Vojin Bakić and the Partizan hospital.

Three research problems are formulated:

a) To explore the sense of community and differences in the sense of community, taking into account socio-demographic characteristics.

b) To explore the valorisation of cultural heritage in Petrova gora and the differences, taking into account socio-demographic characteristics.

c) To assess the correlation between the sense of community and the valorisation of cultural heritage.

Convenience sample of 100 residents of Vojnić municipality participated in this quantitative survey, with an approximately equal share of men and women as well as an equal share of Croats (mostly immigrants) and Serbs (mostly domiciliary). The majority of participants have secondary level education, the average age is 36 and they have lived in the community for 25 years on average. The Sense of community index 2 was used based on McMillan and Chavis's theory, and an instrument for cultural heritage valorisation was constructed with additional questions regarding the practical usage of heritage. On the sense of community scale, we found 5 factors (the original instrument is validated with a four-factor structure): emotional significance of community attachment, recognised community identity, community influence on individuals and the surroundings, community leadership and problem-solving, contacts with community members. The instrument for the valorisation of cultural heritage has a four-factor structure: personal emotional relation towards heritage, behavioural component of valorisation, having an interest toward heritage and the significance of heritage for the citizens. Due to a lower Cronbach's alpha reliability, the third and fourth factors are not included in the analysis.

Regarding sense of community, the results showed the following:

- On average, participants show a low sense of community. The higher results were identified for the "community contacts" factor, somewhat lower regarding the emotional significance of community attachment and recognised community identity. 
The lowest assessments are for community influence on individuals and the surroundings and community leadership and problem-solving.

- There are no differences for any dimension of the sense of community between men and women.

- Younger residents have higher assessments of community leadership and problem solving, while more educated residents have higher assessments of community influence on individuals and surrounding. Other differences in connection to age and education are not found.

- There are no statistically significant differences concerning how long someone has lived in the community.

- Croats, in comparison to Serbs, have higher average assessments of recognised community identity and community influence on individuals and the surroundings, while also having less contact with other community members.

- Immigrant residents (mostly Croats), in comparison to the domiciliary population, on average, have a higher sense of community, have a higher appreciation for community identity, are more positive towards community influence as well as its leadership and problem-solving.

Regarding valorisation of cultural heritage, the results are as follows:

- On average, the residents have a high valorisation of heritage and an even higher emotional relation towards heritage, and a bit lower (but still solid) behavioural component of valorisation. They recognise the possibilities for its usage in art work, tourism, sports and recreation, but not for political purposes (it is seen as somewhat of a taboo).

- Women on average visit heritage sites more often than men.

- There are no statistically significant differences in valorisation regarding age nor length of residence in the community.

- More educated participants see more possibilities for the use of heritage in political activities.

- Serbs, in comparison to Croats, have higher average assessments of heritage valorisation both in the emotional and behavioural component and perceive more possibilities in art and tourism.

- Domiciliary residents, in comparison to immigrants, have higher average assessments of heritage valorisation both in the emotional and behavioural component, and perceive more possibilities for their usage in general.

The results show a statistically significant correlation between heritage valorisation and sense of community as greater emotional significance of community attachment and more contacts with community members correlate with higher total scores in valorisation and particularly the behavioural component. Heritage sites are more often visited by those with more contacts with others in the community. There is no significant correlation between the sense of community and the possibilities for practical usage of heritage.

To conclude, some unexpected results were found indicating that sense of community is not related to what is usually considered its predictor: domiciliary status, the 
length of residing in a community and belonging to majority ethnic groups at the local level. Contrary to that, immigrant residents, mostly Croats, that have lived in the community for shorter periods than the domiciliary population express an even higher sense of community in some dimensions (except contacts with community members). We can assume that their sense of community is empowered by the fact that Croats are the majority at the national level and ethnic relations are reflected at the local level regardless of the actual ethnic ratio.

On the other side, the domiciliary residents (mostly Serbs) that have lived in the community for a longer period have a higher valorisation of the heritage of Petrova gora, which is one of the most famous symbols of the community. Regardless of ethnicity, both groups have higher heritage valorisation than their sense of community. This indicates that heritage valorisation is still disintegrated from the local identity, but local identity can be reconstructed by using heritage as a component of its empowerment.

Local identity is both a process and an outcome of community dynamics, and heritage could be an integral part of it or strengthen it if people were more educated (particularly those with secondary education and young people) and if they had more direct experiences with the heritage through cultural activities. Heritage valorisation and sense of community could be mutually strengthened, and, if strengthened, could contribute to community development in the future.

KEY WORDS: sense of community, cultural heritage, heritage valorisation, community identity, community development 